
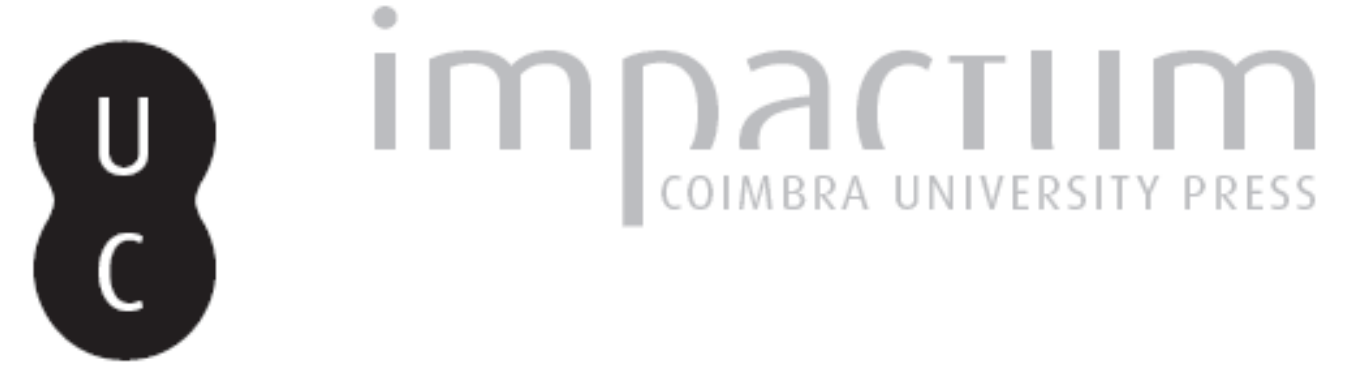

\title{
Em que língua pensas?: a entrada da língua portuguesa na filosofia
}

Autor(es): Henriques, Marisa das Neves

Publicado por: Imprensa da Universidade de Coimbra

URL persistente:

URl:http://hdl.handle.net/10316.2/42831

DOI:

DOI:http://dx.doi.org/10.14195/0872-0851_48_8

Accessed : $\quad$ 26-Apr-2023 11:09:28

A navegação consulta e descarregamento dos títulos inseridos nas Bibliotecas Digitais UC Digitalis, UC Pombalina e UC Impactum, pressupõem a aceitação plena e sem reservas dos Termos e Condições de Uso destas Bibliotecas Digitais, disponíveis em https://digitalis.uc.pt/pt-pt/termos.

Conforme exposto nos referidos Termos e Condições de Uso, o descarregamento de títulos de acesso restrito requer uma licença válida de autorização devendo o utilizador aceder ao(s) documento(s) a partir de um endereço de IP da instituição detentora da supramencionada licença.

Ao utilizador é apenas permitido o descarregamento para uso pessoal, pelo que o emprego do(s) título(s) descarregado(s) para outro fim, designadamente comercial, carece de autorização do respetivo autor ou editor da obra.

Na medida em que todas as obras da UC Digitalis se encontram protegidas pelo Código do Direito de Autor e Direitos Conexos e demais legislação aplicável, toda a cópia, parcial ou total, deste documento, nos casos em que é legalmente admitida, deverá conter ou fazer-se acompanhar por este aviso.

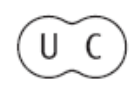




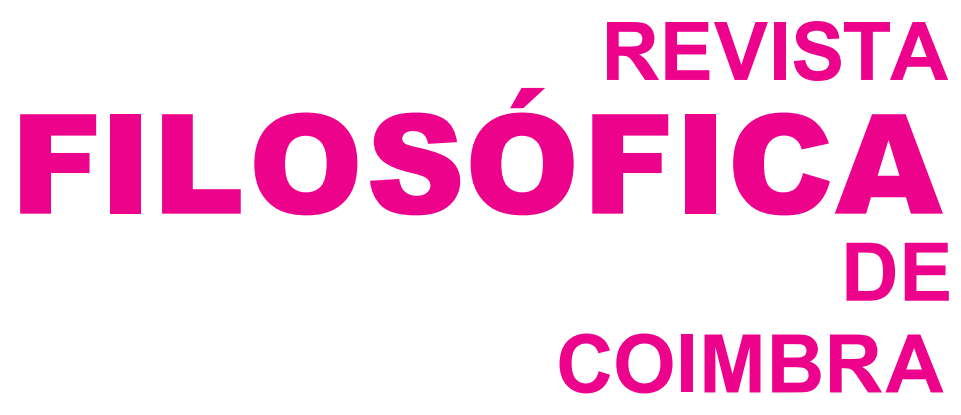

vol. 24 - número 48 - outubro 2015

vol. 24 - número 48 - outubro 2015

Fundação Eng. António de Almeida

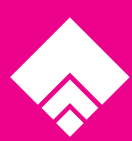




\title{
EM QUE LÍNGUA PENSAS? A ENTRADA DA LÍNGUA PORTUGUESA NA FILOSOFIA
}

\author{
MARISA DAS NEVES HENRIQUES*
}

Resumo: Neste artigo propõe-se a abordagem da Filosofia em Portugal não tanto pelo critério geográfico, mas antes linguístico. A produção de um pensamento filosófico em língua portuguesa a partir do século XV merece ser assinalada para que se trace uma panorâmica mais completa, e talvez mais justa, da história da filosofia lusa no período medievo. Fruto de um esforço de apropriação do legado filosófico clássico, a língua portuguesa participa nesse processo de laicização do pensamento político e das estruturas sociais, fomentado pela cultura de corte. Caberá à Dinastia de Avis inaugurar esse trajeto de criação de um léxico filosófico em português.

Palavras-chave: estoicismo, Dinastia de Avis, língua portuguesa, léxico filosófico, saudade.

Abstract: This paper intends to develop an approach to medieval Philosophy in Portugal, focusing its analysis on linguistic aspects. It is considered that the existence of a philosophical though during the XVth century should be taken into account to proceed to a widely historical adjustment of the philosophical frame in Portuguese Middle Ages.

During this time lapse, the Portuguese language reflects the social and political desires of a laymen audience, especially under the example of House of Avis, interested in recapture the stoic legacy. The major consequence is the enrichment of the Portuguese philosophical lexicon.

Keywords: stoicism, House of Avis, Portuguese language, philosophical lexicon, saudade.

A presente reflexão está dividida em duas partes interdependentes, por tratarem da filosofia em Portugal em língua portuguesa na Idade Média, mas

* Doutora em Filosofia pela Universidade de Coimbra e membro do Centro de Literatura Portuguesa da mesma universidade; marisaneves.henriques@gmail.com 
com relativa autonomia de leitura. Ambas partilham, porém, o mesmo desígnio - de repensar a nossa filosofia à luz do binómio pensamento / estado de língua - e um sentido afim - de revalorização do pensamento filosófico em vernáculo nos séculos XIV e XV.

Além de algum trabalho analítico, realizado a partir de textos monásticos e de escritos filosóficos saídos do punho da Dinastia de Avis, procurar-se-á deixar, ao longo das próximas páginas, algumas pistas que incentivem futuros investigadores a desbravar estas matérias, ainda tão pouco aprofundadas.

\section{História de um desenraizamento}

Trânsfuga por espinhosas circunstâncias pessoais e políticas ao idioma de seu pai, o Condestável D. Pedro, futuro rei de Aragão, redigia em pleno século XV, mergulhado nas raízes do exílio, alguma da sua produção literária visivelmente marcada por um tom de outonal desencanto reflexivo. Sem o brilho de Brunetto Latini que em língua não materna dera a lume o seu Trésor, dotando-a de um renovado aparato conceptual e filosófico, nem com a versatilidade de João de Meung que tinha entrelaçado a escrita do Roman de la Rose com a tradução do De Consolatione Philosophiae, o Infante português faz, no entanto, jus à dinastia inaugurada pelo Mestre de Avis por meio do desvelo que vota às Letras e ao exercício da escrita enquanto acto de cultura e fruto do ócio literário que desenfada e actua terapeuticamente sobre o espírito.

Por detrás da escolha linguística que instigaria o autor das Coplas del Menosprecio e Contempto de las Cosas Fermosas del Mundo a utilizar o castelhano ${ }^{1}$ num tempo em que a Ínclita Geração de seu avô engalanara já a prosa em língua portuguesa de uma saborosa verve, escondiam-se razões de Estado, agudizadas talvez pela deriva geográfica e pelo solipsismo de quem conversava com os livros para apaziguar a alma, dividida entre o sangue lusitano e aragonês, mas sobretudo lacerada por contrariedades governativas e vários desgostos pessoais inefáveis. Sabemos, aliás, pela secular tradição literária que essas eram condições bastante favoráveis à produção filosófica.

1 Vd. Condestável D. Pedro, dedicatória da Sátira de infelice e felice vida in: Obras Completas do Condestável Dom Pedro de Portugal, introd. e ed. diplomática de Luís Adão da Fonseca (Lisboa: Fund. Calouste Gulbenkian, 1975), 9: "Et, sy la muy insigne magnifiçencia vuestra demandare qual fue la causa que a mi movio dexar el materno vulgar, e la seguinte obra en este castellano romançe prosseguir, yo respondere que, como la rodante fortuna com su tenebrosa rueda me visitasse, venido en estas partes, me di a esta lengua, mas costreñido de la neçessidat que de la voluntad." 
Não obstante, teremos de aguardar pelo século XVI para ver nascer uma acrisolada questão linguística em torno da primazia da língua castelhana face à de Camões, golpe a que João de Barros responderá com aceso patriotismo ${ }^{2}$, já para não falar da confiança do nosso cientista Pedro Nunes na sua língua materna, como meio fidedigno de transmissão das últimas descobertas científicas, ou do encómio linguístico de Pero Magalhães Gândavo ${ }^{3}$.

É tão simbólica quão retoricamente eficaz a explicação das circunstâncias de criação dos mil versos do Condestável, em contra-corrente com o bulício da feira de Medina del Campo, que o leva a repousar os olhos em "el libro nombrado «Ecclesiastes», adonde el sabio vigurosamente demuestra la vanidat de las cosas terrenas, cuya abtoridat tanto es mas de presçiar, quanto aquel rey ha seydo mas abondado de todos los mundanos bienes, mas poderoso e mas esçientiffico que todos los otros" 4 .

Tal como fora apanágio da sua família, a imagem do príncipe enformado por valores cristãos e em demanda da virtude detecta-se na missiva sobre a política de Marrocos, onde prevalece a ideia de que o rei digno desse nome se há-de tornar cavaleiro espiritual e émulo de Salomão, o representante por excelência da voz da sabedoria. Homem de ascendência culta, o filho de D. Pedro dominava várias línguas, como se pode constatar pelos muitos volumes da sua biblioteca pessoal, entre os quais se encontra inventariado por punho catalão

"Item altre libre de forma de full, scrit en pergamins, ab posts cubertes de cuyro vermell empremptades, ab quatre scudets e ab dues anelletes en cascun scudet tot dargent daurat, e en los scudets son les armes de portugal,e en les altres dos la roda de la fortuna, ab dues tiretes de seda violada, intitulat en la cuberta ab letres dor, Este he o livro do orto desposo etc. É feneix en la penúltima carta e quando chego etc. Es scrit a coróndells, en vulgar portugues 5 ."

2 João de BARros, Diálogo em louvor da nossa linguagem, lettura critica dell'edizione del 1540 a cura de Luciana Stegagno Picchio (Modena: Mucchi, 1959), 80: "Çerto a quem nam faleçer matéria e engenho pera demonstrar sua tençam, em nossa linguagem nam lhe faleçeram vocábulos: porque de crer é que se Aristóteles fora nosso natural, nam fora buscar linguagem emprestada pera escrever na filosofia e em tôdalas outras matérias de que tratou. E se lhe faleçera algum termo soçinto, fizera ô que vemos em muitas partes aos presentes: os quaes quando careçem de termos theologaes, os theólogos pera intendimento real da cousa ôs compuseram, e assy os filósofos mathemáticos, juristas, médicos: todos antre sy trazem termos que nam sam latinos nem gregos, mas casy hum vasconco, de artes, em que os homẽes gastam tantos annos".

3 Pêro de Magalhães GÂNDAvo, Diálogo que adiante se segue em defensão da mesma língua, introd. de Helena Carvalhão Buescu ( Lisboa: IN-CM, 1981). Para períodos literários mais avançados, $V d$. Maria Helena da Rocha Pereira, "Elogios da Língua Portuguesa", Mathésis 15 (2006), 257-273.

4 Condestável D. Pedro, Obras, 183.

5 Serafim da Silva Neto, Textos Medievais Portugueses e seus Problemas (Rio de Janeiro: Ministério da Educação e Cultura, 1956), 125. 
Habent sua fata libelli. Daí que o Orto do Esposo, importante título da literatura espiritual portuguesa de Quatrocentos, constando também do acervo bibliográfico do seu tio D. Duarte, talvez inadvertidamente, mas num interessante diálogo, ecoasse à semelhança das Coplas, a mediação do Eclesiastes e de Severino Boécio no anúncio da vanidade do mundo e no incitamento transcendental à "vera felicidad, / La qual no peresce jamais in eterno, /Mas dura por siempre su eternidad ${ }^{6 "}$. Imaginemos que o Condestável teria lido o extenso Livro IV do Orto, onde se fazem o apelo ao despojamento e o convite ao sedutor regozijo celestial. Aí, D. Pedro de Aragão (que ainda assim não se inibe de convocar esteticamente os deuses pagãos) teria encontrado motivos de sobra para desdenhar da ciosa permanência humanal neste mundo e para tecer a apologia do menosprezo pelos impérios e reinos mundanos ${ }^{7}$.

Para além da sua relação com a espiritualidade cisterciense e da empatia pelos escritos estóicos, o Condestável de Portugal menciona nas abundantes glosas das Coplas figuras gradas da filosofia antiga como Sócrates, "sabio divinal: e maravilloso, asi en sciencia / como en claras costumbres", "Diógenes Laércio 9 ou o autor das Cartas a Lucílio, "hombre eruditissimo", "de vida mui continente" 10 , aproximando-os da mundividência cristã.

Apesar de morrer antes do aparecimento de um dos primeiros incunábulos em língua portuguesa que, com assinalável acolhimento em Portugal, aufere as graças da Corte, ${ }^{11}$ o Condestável D. Pedro, cultor de um espírito de erudição peninsular ${ }^{12}$ mantém-se fiel a uma predilecção ético-moral de pen-

${ }^{6}$ Condestável D. Pedro, Coplas del menosprecio e contempto de las cosas fermosas del mundo, edição preparada por Aida Dias (Coimbra: Almedina, 1976), 51.

7 Condestável D. Pedro, Coplas, 53: "Menospreciad aquell'alta cumbre / De los imperios e de los reynados, / Pues non contiene en si clara lumbre / Ni faze los ombres bienaventurados"

8 Condestável D. Pedro, Coplas, 94. O elogio a Sócrates surge na glosa em que o filho do Regente D. Pedro apresenta as circunstâncias da morte do filósofo grego, mostrando conhecer o Fédon de Platão. Apesar de se tratar de uma referência textual muito estropiada, estamos em crer que se procura recordar, do Epílogo, as impressivas palavras de Sócrates dirigidas a Críton (e não a Lícias) antes de tomar a cicuta.

9 Condestável D. Pedro, Coplas, 81: "Diogenes, de que aqui se faze mencion de marauillosa vida e de claras /costumbres, fue ornado de muy mas claro e libre spiritu, philosofo, tanto fa/moso que entre todos los otros el es hauido por singular, singular, specialmente en /menospreciar el mundo e las cosas vanas del."

10 Condestável D. Pedro, Coplas, 57.

11 Lembre-se que a sua mãe, D. Isabel de Urgel, manda fazer uma cópia dessa tradução da Vita Christi de Ludolfo da Saxónia para uso pessoal.

12 Leia-se o proveitoso artigo de Isabel Beceiro PitA, "La recepción de la cultura aristocrática castellane en el Portugal de los Avis" in: Estudos em Homenagem do Professor Doutor José Marques (Porto: Un. do Porto Edições, 2006, vol. 2), 221-235; e ainda Adeline RUCQUOI, "Rois et princes portugais chez les auteurs castillans du XV ${ }^{\text {ème }}$ siècle", Península 0 (2003), 39-51, que recorda a relação do Condestável com o Marquês de Santillana. 
dor didáctico nutrida pela literatura de príncipes, que sabe honrar pela escrita o que o infortúnio lhe ditara e a morte da sua irmã viria a onerar ${ }^{13}$.

Se seguirmos a lição de Mário Martins que em algumas obras e biografias como esta reconheceria decerto uma atitude filosófica ou, pelo menos, o uso de determinados filosofemas com interesse intemporal, compreendemos que ainda estamos longe de conhecer com propriedade a história da filosofia e da cultura em Portugal no século XV, bem como das línguas que a irrigam ${ }^{14}$. Provavelmente, só uma atitude mais permeável a outros textos e figuras históricas nos permitirá completar algumas das lacunas que inibem a narração de uma história da filosofia em Portugal a partir da língua, em favor do critério mais alargado e antigo da geografia.

Voltemos, no entanto, um pouco atrás, à época em que sobre a língua portuguesa se erigiram as novas fronteiras simbólicas do reino, deixando por instantes na sua solidão o Condestável D. Pedro, intelectual poliglota que se terá apoiado no estudo meditativo como refrigério para as dores da alma e da distância geográfica em relação à alma mater.

\section{Uma língua nacional}

É conhecido o talento poético de D. Dinis, espraiado por um cancioneiro individual onde se cultivam topoi e géneros literários variados e onde se assiste ao "tratamento de aspectos relacionados com as dimensões psicológico-sentimentais do processo amoroso ${ }^{15}$," através de uma linguagem permeada ora de requintes feminis, ora de uma "coita" assumida em primeira pessoa pelo amante. Desde o sofrimento amoroso dionisino que levaria o sol a encobrir-se, passando pela perda do "sem e [d]a razom" e pelo desejo de morte, até à crítica social de "Mui melhor ca m'eu governo", encontram-se motivos de sobra para acompanhar a apropriação galego-portuguesa do

13 Vd. Condestável D. Pedro, Prólogo da Tragedia de la Insigne Reina Dona Isabel, 307: "Correr los mas, segund yo pienso, que, seyendo revocado del injusto destierro, venido a la paternal tierra, algund consuelo e descanso me /fuesse de tal venida al grave dolor que ove la reyna mi señora e hermana (...)."

14 De facto, é multímoda a realidade linguística que encontramos em Portugal no período de Quatrocentos e que poderemos sintetizar com a referência a títulos como o Leal Conselheiro, de D. Duarte, o De republica gubernanda per regem de Diogo Lopes de Rebelo, o Horologium Fidei de André do Prado, o Cancioneiro de Garcia de Resende, antologia poética onde português e castelhano se irmanam.

15 Jorge OsóRIo, “D. Dinis: o rei, a língua e o reino”, Máthesis 2 (1993), 28. 
vocabulário cortês ${ }^{16}$, encastoado, por vezes, em estruturas verbais da tradicional sociedade feudal.

Mas, não sendo negligenciável o facto de sob a égide de D. Dinis se alcançar o esplendor do trovadorismo, que o pranto do jogral João assinala ${ }^{17}$, de maiores consequências ainda é a instituição do português como língua oficial do reino. Muito embora percorridas as cartas da chancelaria de seu filho, aí encontremos registos em galego-português ${ }^{18}$ e, apesar de os mais antigos documentos originais sobreviventes serem de finais do XII e inícios do século XIII ${ }^{19}$, é com o neto de Afonso X que a identidade do território nacional se fortalece por meio de um idioma que, nascido a norte, nas margens do rio Minho, viria a tornar-se único ${ }^{20} \mathrm{e}$, ao mesmo tempo, a representar um símbolo de coesão. Definidas as fronteiras, e conquistado finalmente um ambiente de paz para o reino português, torna-se propícia a instauração de horizontes culturais mais favoráveis ao florescimento literário e ao aplauso de novas formas de expressão artística.

16 OsóRIo, "D. Dinis", 24: "a variedade de situações e de temas que o rei procurou explorar [indicia] que a língua vulgar utilizada no canto cortês usufruía de suficiente dignidade para que o exercício do dizer poético pudesse constituir uma marca identificadora da corte do rei e, por conseguinte, do seu Reino e senhorio."

17 Leia-se apenas a primeira estrofe: "Os namorados que troban d'amor / todos devian gran doo fazer, / e non tomar en si nen un prazer, / porque perderon tan bõo senhor / como el-rei D. Denis de Portugal, / de que non pode dizer nen un mal / homen, pero seja posfazador." $(62,2)$

18 Vd. Chancelaria de Afonso III, ed. de Leontina Ventura e de António Resende de Oliveira (Coimbra: Imprensa da Universidade, 2006, 2 vols.), especialmente duas cartas de 10 de junho de 1255: "Carta de foro hereditatis de Teloes de Aguyar" e "Carta de foro de Condudo".

19 Em relação aos textos não literários, chegaram até nós a Notícia de Fiadores (1175), a par da Notícia de Torto (c. 1214) e do Testamento de Afonso II (1214), embora devamos acentuar, com Gavilanes LAso, História de la literatura portuguesa (Madrid: Cátedra, 2000), 30, a anterioridade de indícios textuais da nossa proto-língua: "Las primeras palavras portuguesas, o más propiamente de lo que se ha venido llamando gallego-portugués, aparecen en documentos del siglo IX, redactados en un artificioso latín bárbaro (lenguaje irregular, jerga de escribanos y notarios) pero con intromisión del romance o lengua hablada. (...) Dos piezas líricas, las cantigas de João Soares de Paiva y de don Sancho I (1185-1211), fechadas alrededor de 1200, pasan por ser las primeras manifestaciones literárias gallego-portuguesas".

$V d$. o incontornável estudo de Lindley CINTRA "Sobre o mais antigo texto não-literário português: A Notícia de Torto", Boletim de Filologia 31 (1990), 21-77. Revelador da matriz latina, pelo recurso a uma grafia latinizante, o Testamento de Afonso II dá, no entanto, conta de uma regularização na escrita, apresentando já o uso de ch para grafar a africada [tš].

20 Cf. José Joaquim Nunes, Compêndio de Gramática Histórica Portuguesa (Lisboa: Livraria Clássica Editora, 1960). 
Nem Francisco Brandão ${ }^{21}$, nem o autor de Origem da Língua Portuguesa $^{22}$ poupam nos elogios ao rei-Trovador, realçando não só o seu papel em prol da valorização da língua materna, como a sua preocupação em enriquecê-la através do incitamento à tradução ${ }^{23}$ e do manuseio de bons modelos literários. Na verdade, esquissava-se também no espírito do monarca a necessidade de dilatar os nossos horizontes historiográficos - o que com indeléveis marcas na percepção da escrita como memória o seu filho bastardo D. Pedro potenciaria ${ }^{24}$ - e de criar o Estudo Geral ${ }^{25}$, cuja intenção primeira era dotar o Estado de novos funcionários e de evitar a dispersão dos alunos pelas Universidades de Bolonha, de Paris e Salamanca.

Apesar de se manter o prestígio do latim no ensino, e de nem tudo correr de feição nem com o fulgor esperado na Universidade ${ }^{26}$, a língua portuguesa começava a encontrar o eixo geográfico daquela que viria no futuro a ser a norma padrão e a munir-se de linguagens específicas, que, por um lado, a expandiam e habilitavam terminologicamente, por exemplo, nos domínios da cinegética e da medicina veterinária ${ }^{27} \mathrm{e}$, por outro, respondiam à premên-

21 Francisco Brandẽo, Quinta Parte da Monarchia Lusytana (Lisboa: Officina de Domingos Rodrigues, 1762), 7-10.

22 Duarte Nunes de Leño, Chronica delRei Dom Dinis, in Crónicas dos Reis de Portugal (Porto: Lello \& Irmão - Editores, 1975), 236.

23 Afonso X, Historia Geral de Hespanha, trasladada em portuguez por el-rey D. Diniz... (Coimbra: Imprensa Litteraria, 1863).

24 Cf. Portvgaliae Monvmenta Historica. Livro de Linhagens do Conde D. Pedro, edição crítica por José Mattoso (Lisboa: Academia das Ciências / IN-CM, 1980, vol. II); e Crónica Geral de Espanha de 1344, ed. crítica do texto português de Lindley Cintra (Lisboa: IN-CM, 2009). Leia-se ainda a introdução a Crónica General de España de 1344, ed. crítica del texto español de Diego Catalán y María Soledad de Andrés (Madrid: Editorial Gredos, 1970).

25 Segundo Mário Brandão, em A Universidade de Coimbra. Esbôço da sua História (Coimbra: Atlântida Editora, 1937), 13-14, já no reinado de seu pai estavam reunidas as condições políticas e culturais para que existisse ensino universitário entre nós: "Portugal atingiu então os limites continentais que ainda hoje conserva a bem dizer intactos, os vestígios da crudelíssima luta que arrancara a coroa ao desventurado D. Sancho II gradualmente se foram apagando, e no trono senta-se agora um monarca amigo dos poetas que reúne à sua volta uma corte de músicos e trovadores, e que durante uma longa permanência de 16 anos em França se afeiçoara tanto à sua brilhantíssima cultura que escolheu para mestres do seu filho e herdeiro D. Denis, um francês de Cahors, Ayméric d'Ebrard, e um português, doutor pela universidade de Paris, Domingos Jardo."

26 Vd. Manuel Augusto Rodrigues, "Notas sobre a Universidade de Coimbra desde as origens (1290) até à fixação definitiva em Coimbra (1537)", in: Estudos em homenagem ao Professor José Marques, vol. 3, 111-128.

27 Livro d'Alveitaria do Mestre Giraldo, edição de Gabriel Pereira, Revista Lusitana 12 (1909), 1-60 e Mestre Giraldo, Tratado das enfermidades das aves de caça: segun- 
cia de divulgação do saber em vulgar.

Uma das faces visíveis deste impulso é a trasladação para o nosso idioma do Fuero Real de Afonso $\mathrm{X}^{28}$, que aclimatava a linguagem jurídica à língua de D. Dinis, também ela herdeira do Direito romano. Na verdade, o ocaso da poesia trovadoresca e o próprio esmaecer do feudalismo contribuíram para o florescimento da prosa histórica e doutrinária, geradora de novas exigências linguísticas, a que não era alheia a consciência dos constrangimentos do idioma português, nomeadamente no plano lexical.

Às vezes, um denso nevoeiro se interpunha entre o pensamento e a sua forma de expressão, como o confessam D. Duarte e o seu irmão D. Pedro, em passos concretos das suas obras filosóficas, parágrafos fundamentais do ponto de vista metatextual e linguístico para percepcionar à distância angulosidades discursivas subsistentes. Na Vertuosa Benfeytoria é-nos dito, por exemplo, que "o nome de cada hũa cousa he o primeiro conhecimento que sse della pode aver e per elle devem seer as propriedades do seu significado mostradas" 29 . Mas, o que acontecia quando faltavam nomes para designar a realidade pensada? O Infante certifica à época que "non temos, segundo nossa linguagem, vocábulos apropriados" ${ }^{30}$ para espelhar todas as dimensões da vida, porém mantém-se intrépido na tarefa de comunicar na sua língua materna, até por estar consciente de que os cortesãos eram cada vez menos "latinados ${ }^{31}$."

do um manuscrito do século XV, (Lisboa: Of. Typ. da Calçada do Cabra, 1909). Sobre estas duas obras, vide Carolina Michaëlis de VAsconcelos, "Mestre Giraldo e os seus tratados de Alveitaria e Cetraria”, Revista Lusitana 13 (1910), 149-432; e, relativamente às estruturas linguísticas próprias dos textos de especialidade que enformam o Livro de Alveitaria, $v d$. António Franco, "O Livro de Alveitaria do mestre Giraldo numa perspectiva da Linguística de Texto da Especialidade", in: Os Reinos Ibéricos na Idade Média. Livro de Homenagem ao Professor Doutor Humberto Carlos Baquero Moreno, coord. por Luís Adão da Fonseca (Porto: Civilização, 2003, vol. 1), 209-217.

28 Afonso X, Foro Real, edição e estudo linguístico de José de Azevedo Ferreira (Lisboa: IN-CM, 1987, 2 vols.). O segundo volume da obra, constituído por um glossário, fornece-nos um importante manancial de informação no âmbito do léxico especializado, que, todavia, não terá sido devidamente enfatizado nas conclusões do volume I. $V d$., ainda sobre este tema, o estudo de Clara Barros, Versões Portuguesas da Legislação de Afonso X-Estudo Linguístico-Discursivo (Porto: Un. Porto Edições, 2010).

29 Infante D. Pedro e Frei João de Verba, Livro da Vertuosa Benfeytoria, ed. de Adelino Calado, (Coimbra: Por ordem da Universidade, 1994), I, IV, 19. Doravante, as citações dos passos desta obra serão feitas pela seguinte ordem: livro, capítulo, número de página.

30 Infante D. Pedro e Fr. João de Verba, Livro, I, IV, 20.

31 Cf. dedicatória de Livro dos Oficios de Marco Tullio Ciceram o qual tornou em linguagem o Ifante D. Pedro, ed. crítica de Joseph Piel (Coimbra: Por ordem da Universidade, 1948), 2. 
Mas, não eram apenas os problemas lexicais que ensombravam a expressão escrita em língua portuguesa, como revela o Infante no prefácio que testemunha o seu empenho em dar a conhecer a teoria do benefício:

[Séneca] "compôs em latim sete pequenos livros, dando ensinança aos homẽes que desto razoadamente quisessem usar, dos quaaes a ssentença e ordenança, porque he curta e muito scura, e do falar que agora usamos desacustumada, trabalheyme de a ensirir toda com outras cousas que a esto eram compridoyras, fazendo nova compilaçom proveytosa a mim e a todollos outros que son obligados de praticar o poder que tẽe pera fazerem boas obras. (...) rogo a todos que soportem minha rudeza onde algũas minguas forem achadas. E os que menos leterados forem do que eu son non se anogem dalgũas palavras latinadas e termos scuros que en taes obras se non podem scusar ..." ${ }^{\prime 32}$.

A prosa acusava certa aridez e redundância, assim como o uso de estratégias de clarificação e sucessivos ajustamentos e redefinições de conceitos, sobretudo daquela noção que se afigura crucial no tratado e aparece, desde logo, no título. Escalpelizemos um pouco os recursos usados pelos autores da obra para explanar a noção de benefício:

\begin{tabular}{|l|l|}
\hline Conceito de benefício & \multicolumn{1}{|c|}{ Localização na obra } \\
\hline $\begin{array}{l}\text { Ideia-base: } \\
\text { O benefício faz parte } \\
\text { de uma estrutura } \\
\text { social harmónica. }\end{array}$ & $\begin{array}{l}\text { [Deus] "liou spiritualmente a nobreza dos principes e } \\
\text { a obedeença daqueles que os ham de servir com doçe e } \\
\text { forçosa cadea de benfeytoria, per a qual os senhores dam } \\
\text { e outorgam graadas e graciosas mercees, e os sobditos } \\
\text { oferecem ledos e voluntariosos serviços aaquelles a que } \\
\text { por natureza vivem sojeitos..." }\end{array}$ \\
\hline Origem divina & $\begin{array}{l}\text { "a virtuosa bemfeytoria nom convem aos homẽes } \\
\text { senom per aazo do movimento do Senhor Deus, do qual } \\
\text { ella principalmente procede." }\end{array}$ \\
\hline $\begin{array}{l}\text { Apresentação da } \\
\text { "complexidade" do } \\
\text { conceito }\end{array}$ & $\begin{array}{l}\text { "E este nome 'benefficio' ou 'benfeyturia' tem muytas } \\
\text { significações. Por estremarmos de todas a que he } \\
\text { mais convinhavel a este proposito saybhamos que o } \\
\text { benefficio e benfeytoria podem aver tres comparações." }\end{array}$ \\
\hline
\end{tabular}

32 Infante D. Pedro e fr. João de Verba, Livro, II, 15. 


\begin{tabular}{|l|l|}
\hline $\begin{array}{l}\text { Definições de } \\
\text { benefício }\end{array}$ & $\begin{array}{l}\text { "Benefficio he affeyçom virtuosa de proveytar a } \\
\text { outrem, mostrada per obra. (...) A iia deffiniçom sguarda } \\
\text { principalmente ao dom, que he cousa outorgada, e diz } \\
\text { assy: benefficio he bem feyto a outrem com entençom } \\
\text { de lhe prestar." }\end{array}$ \\
\hline Recurso à paráfrase & $\begin{array}{l}\text { "Benfeytoria proveytosa he benefficio que faz } 26 . \\
\text { melhoramento ou ajuda aa vida daquelle que o recebe." }\end{array}$ \\
\hline $\begin{array}{l}\text { Redefinição com base } \\
\text { no étimo latino e na } \\
\text { sensibilidade cristã }\end{array}$ & $\begin{array}{l}\text { [Deus] "fundou spiritual vertude, que he chamada } \\
\text { caridade e amor, da qual vertude nace hũu aucto dentro } \\
\text { em nós que sse diz en latim 'benivolencia' que quer } \\
\text { dizer 'benquerença'. E depois deste aucto procede outro } \\
\text { fora de nós que sse chama en latim 'benefficencia' e em } \\
\text { nossa linguagem 'benfeyturia'." }\end{array}$ \\
\hline $\begin{array}{l}\text { Conceitos } \\
\text { relacionados com o de } \\
\text { benefício }\end{array}$ & $\begin{array}{l}\text { Acto, intenção, vontade. } \\
\text { "E pois que a entençom he aucto da voõtade e o } \\
\text { benefficio procede della mesma, razom he de elle seer } \\
\text { per entençom determinado." }\end{array}$ \\
\hline $\begin{array}{l}\text { Transversalidade } \\
\text { social do verbo pedir } \\
\text { invocadas }\end{array}$ & $\begin{array}{l}\text { "vocabullo 'pedir', qual sempre em nossa linguagem he } \\
\text { acostumado dos pequenos aos mayores". }\end{array}$ \\
\hline
\end{tabular}

Provavelmente, pela mão de Frei João de Verba alargava-se o leque de referência a auctoritates clássicas, entre as quais se encontram Aristóteles, Platão, Plínio, São Tomás, Egídio Romano, entre muitos outros ( $v d$. apêndice 1). Na verdade, sob o patrocínio da corte trilhavam-se já caminhos de nobilitação individual que passavam pelo cultivo do intelecto e pela criação de livrarias régias, num claro sinal de que o exercício do poder tinha de ser esclarecido $^{33}$ e de que, à revelia do panorama um pouco céptico traçado por

33 Vd. D. Duarte, Leal Conselheiro, ed. crítica de Maria Helena Lopes de Castro (Lisboa: IN-CM, 1998), LI, onde, para sustentar a opinião de que o rei deve investir-se de requisitos especiais, o autor cita Aristóteles, Platão, bem como o Policraticus e o Regimento 
Joaquim de Carvalho ${ }^{34}$, poderá desenhar-se um outro ângulo de análise da filosofia em solo lusitano. Tomando o repto de Imbach, a filosofia laica europeia, desenvolvida nos meios áulicos, vem reforçar a convicção de que a filosofia medieva é poliédrica e não se atém a um só espaço nem ao empenho dos clerici $^{35}$, extravasando finalidades religiosas e a concentração unidirecional num público monástico.

Depois do apoio régio aos mosteiros de Santa Cruz de Coimbra ${ }^{36}$ e de Alcobaça, onde importantes acervos se constituíam, chegava a vez de o leigo (uma das primeiras palavras de sabor nacional) adquirir conhecimentos sem estar limitado pelo (pre)domínio da língua de cultura. Aliás, se folhearmos o belíssimo Livro de Horas quinhentista editado em fac-símile pela Biblioteca Nacional, e nos fixarmos no título escolhido pelo editor - Rezar em português ${ }^{37}$ - percebemos, de imediato, o alcance da assunção da língua portuguesa como idioma veicular e piedoso junto dos leigos. Quantos fiéis, em pleno século XX, terão recitado, quase maquinalmente, o Tantum ergo sacramentum sem sorverem o significado do que diziam? Mais reduzido ainda era no período medievo o privilégio de suster entre as mãos as orações que louvariam o Senhor e os santos da devoção pessoal do proprietário do Livro de $\operatorname{Horas}^{38}$, aí incluídos, às vezes, a seu pedido.

Paralelamente ao ensino monacal e universitário emergia, então, uma filosofia laica orientada para fins práticos - no âmbito da ética, da moral e da política - que procurava responder a questões profissionais e às aspirações da aristocracia e da realeza ${ }^{39}$, através de uma sintaxe mais desen-

dos Principes. Também o seu irmão afirma na Vertuosa Benfeytoria, II, XXII, 135, que "o poboo leygo nunca tam mal seria regido pelos que fossem sabedores, que mayor proveyto nom tirassem que dos ignorantes que a ssy meesmos empecem e a outrem nom prestam".

34 Joaquim de Carvalho, Desenvolvimento da Filosofia em Portugal durante a IdadeMédia (Coimbra: separata de O Instituto 95, 1927).

35 R. Імвасн, Laien in der Philosophie des Mittelalters. Hinweise und Anregungen zu einem vernachlässigten Tema (Amsterdam: B.R. Grüner Company, 1989), 15.

36 Não esqueçamos os documentos de natureza hagiográfica produzidos em Santa Cruz. Sobre este assunto, vd. Hagiografia de Santa Cruz de Coimbra, ed. crítica, tradução e notas de Aires Nascimento (Lisboa: Colibri, 1998).

37 Rezar em Português. Horas de Nossa Senhora segundo costume Romaano..., edição de João José Alves Dias (Lisboa: Biblioteca Nacional, 2009, 2 vols.).

38 Sobre o universo do livro no século XV e, mais especificamente, sobre o seu valor simbólico $v d$. Saul Gomes, "Livros medievais portugueses. Novos elementos para o seu conhecimento", Biblos. Nova Série 3 (2005), 70.

39 Aí radicam os motivos de fascínio de D. Pedro pelo De officiis, que a dedicatória da sua tradução, op. cit., 3-4, deixa transparecer: "E ainda que a vossa Senhoria tenha muitos e mui boos livros que trautam da philosaphia moral, este antre elles deve seer bem prezado. Por que a mayor parte dos outros trautam que cousa som as virtudes, quanto, por que, como devem seer prezadas e como veem hũas das outras, ou dos atamentos que ha entre ssy; 
volta $^{40}$ e de uma língua, cujo domínio se generalizou. Não admirava, por isso, que o estoicismo fosse uma seiva doutrinária apetecida, aplaudindo os nossos pensadores laicos a inclusão de Cícero ${ }^{41}$ e de Séneca no diálogo de autores gizado nos tratados políticos e éticos.

Assim, pela mão da Dinastia de Avis, assistiríamos ao aparecimento de um novo perfil intelectual, sintetizado por Rui de Pina no retrato de D. Duarte:

"foi homem sesudo e de claro entendimento, amador de sciencia de que teve grande conhecimento, e não por descurso d'escolas, mas por continuar d'estudar e ler por bons livros: cá sómente foi grammatico, e algum tanto logico; fez um livro de Regimento para os que costumarem andar a cavallo: e compoz por si outro aderençado á Rainha D. Leonor, sua mulher, a que intitulou o Leal Conselheiro, abastado de muitas e singulares doctrinas, especialmente para os bens da alma ${ }^{42}$."

Portador de uma educação ecléctica, mesmo sem frequentar o Paço das escolas, o filho mais velho de D. João I mostrar-se-ia conhecedor quer da Confessio Amantis de João Gower ${ }^{43}$ e das versões em linguagem da matéria da Bretanha (Livro de Tristam e Merlim), quer de títulos inscritos na literatura de príncipes europeia e de obras portuguesas de ascética e mística. Da sua interessante livraria ${ }^{44}$ constavam o curioso Livro do Buen Amor (que aparece catalogado sob o título O Acipreste de Fyta) e a Corte Enperial, obra anóni-

mas enssynam muy pouco como devemos husar dellas. (...) os outros per a mayor parte screvem da theorica, e a tençom deste he de mostrar a pratica. (...) dos livros qye vi de philosaphia, este avantejdamente enssyna a cobrar o que os outros fazem amar e desejar."

40 Infante D. PEDro, Dedicatória a Livro, 4: "E porque antre muitos ha desvayramento, assy de entenderes como de vontades, desvayradamente foi a obra composta pera o engenhoso e sotil achar delectaçom a seu entendimento, e ao simprez porem nom minguasse atal clareza per que aprender podesse as cousas que a elle convem, e tambem aquelles que filham prazer em novas maneyras de curto falar achassem hi algũu comprimento do que em esto quer o seu desejo, e os que chaão falam e querem ouvyr achassem scriptura segundo seu geyto." (O sublinhado é nosso)

41 Cruz Pontes, "Cícero em Portugal", in: Enciclopédia Luso-Brasileira de Cultura (Lisboa: Verbo, 1967, vol. 5) cols. 395-396; Manuel Cadafaz de MAtos, “A presença de Cícero na obra de pensadores portugueses nos séculos XV e XVI”, Humanitas 46 (1994), 259-304.

42 Rui de Pina, Chronica d'El-Rei D. Duarte (Lisboa: Escriptorio, 1901), III, 26.

43 W. Entwistle e P. Russel, "A Rainha D. Felipa e a sua Côrte", in: Congresso do Mundo Português (Lisboa: Secção de Congressos, 1940, vol. 2), 319-346; Antonio C. OCAÑA, "La traducción portuguesa de la Confessio Amantis de John Gower", Evphrosyne 23 (1995), 457-466.

44 Vd. Manuel Cadafaz de Matos, "D. Duarte, rei e filósofo, a sua livraria e os interesses de um humanismo pré-renascentista", Beira Alta 50 (1991), 527-556; e Aires Nascimento, “As livrarias dos príncipes de Avis”, Biblos 69 (1993), 265-287. 
ma a que o Professor Cruz Pontes reconhece interesse para o estudo da terminologia portuguesa filosófico-teológica ${ }^{45}$, além do Regimento de principes e de obras com carácter de exemplaridade - Julio Cesar, o Livro d'Anibal, o Livro do Conde Lucanor.

De facto, pouco estudado ainda, o léxico filosófico medieval português, na sua relação com a maturação da língua e com as estruturas intelectuais que servem o pensamento abstracto, tem nas obras dadas a lume pela Casa de Avis e por ela conservadas ${ }^{46}$ um notável corpus de investigação no âmbito da Filosofia em Portugal. Basta atentarmos um pouco nas experiências realizadas além-fronteiras por G. Matoré 47 que analisa o vocabulário em harmonia com as redes de sentido que determinam a construção das sociedades e nos trabalhos de Paul Zumthor que procuram restabelecer a relação entre a palavra e a história das ideias" 48 .

Temente a Deus ${ }^{49}$ e timorato no cumprimento de uma conduta moral cristã, D. Duarte imprime aos textos que assina uma forte marca de subjectividade, tecida na sua experiência de vida, ${ }^{50}$ numa altura em que ainda era bastante comum surgir a figura do compilator a reunir polifonicamente auctoritates. Num claro equilíbrio entre o corpo e a mente - que o paterno Livro de Montaria também prescrevia - o monarca não hesita em falar dos benefícios da instrução e da aprendizagem das línguas, ${ }^{51}$ recomendando a

45 Cruz Pontes, Estudo para uma edição crítica do Livro da Corte Enperial (Coimbra: Instituto de Estudos Filosóficos, 1957).

46 Vd. Lênia Mongelli (coord.), A Literatura Doutrinária na Corte de Avis (São Paulo: Martins Fontes, 2001), onde, tomada no seu conjunto, a prosa literária desta época ilustra a ductilidade da língua.

$47 V d$., para a época que nos ocupa, G. Matoré, Le vocabulaire et la société médiévale (Paris: PUF 1985).

48 Paul Zumthor, "Notes sur les champs sémantiques dans le vocabulaire des idées", Neophilologus 3 (1 de julho de 1955), 175-183; id., "Notes sur les champs sémantiques dans le vocabulaire des idées II", Neophilologus 4 (1 de outubro de 1955), 241-249; id., «Pour une histoire du vocabulaire français des idées», Zeitschrift für romanische Philologie 72, 5/6 (1965), 340-362.

49 Segundo relata Fernão Lopes, ao Mestre de Avis se devia o impulso para a tradução dos "avamjelhos e autos dos Apostolos e [d]as epistolas de São Paulo e outros espirituaes livros dos Samtos" (Crónica de D. João I, edição preparada por M. Lopes de Almeida e A. de Magalhães Bastos (Porto: Civilização, 1990, vol. 2), Prólogo, 2. Vd. ainda o testemunho consentâneo de D. DuARTE no Leal, XXVII, 111.

50 D. Duarte, Prólogo do Leal, 9: “Ca sobr'elo mais screvo por que sinto e vejo na maneira de nosso viver, que per studo de livros nem ensino de leterados".

51 D. Duarte, Livro da Ensinança de Bem cavalgar toda sela que fez el-rey Dom Duarte, edição crítica de Joseph Piel (Lisboa: IN-CM, 1986), V Parte, XV, 120-121: "E nossos corpos, se em tempo de mocidade [e] mancebia som leixados em ouciosidade nom se despoendo a boas sciencias ou boas manhas corporaaes ou mesteres, segundo a 
leitura assídua e o estudo de obras de filosofia moral.

Desta feita, tanto o seu Leal Conselheiro como a Vertuosa Benfeytoria do Infante D. Pedro anunciam a entrada da língua portuguesa num decisivo estádio de maturidade, ainda que em luta com a incipiente construção conceptual no domínio filosófico. ${ }^{52}$

Se é certo que entre os reinados de D. Fernando e de Afonso V se dão as principais mudanças na nossa língua ${ }^{53}$, no plano fonológico, os textos dos séculos XIII e XIV testemunham a presença de encontros vocálicos, criados pela síncope de algumas consoantes sonoras intervocálicas (nomeadamente de -d-, -de -g- de -1- e de -n-), que a partir de meados de Trezentos serão progressivamente eliminados por diversos processos, a saber: pela crase (PALATIU $>$ paaço $>$ paço; SEDERE $>$ seer $>$ ser; BONU $>$ bõo $>$ bom), pela criação de um ditongo oral (estades $>$ estaes $>$ estais) ou nasal (MANU- $>$ mã-o $>$ mão), pela epêntese de uma semivogal anterior (TELA $>$ tea $>$ teia) ou nasal palatal (VICINU- > vizĩo > vizinho). Não obstante, a ortografia manteria o seu traço conservador, guardando ainda muitas situações de hiato e registando acentuadas oscilações gráficas, que o Orto do Esposo ${ }^{54}$ e o Bosco Deleytoso, obras de finais do século XIV, ainda assinalam.

Ficamos a dever aos filhos de D. João I a utilização de latinismos ${ }^{55}$ e de novos termos que irrigam o caudal do pensamento filosófico em vernáculo, podendo encontrar-se nos interstícios dos seus escritos pequenas reflexões metalinguísticas que atestam o esforço de contrariar a inefabilidade e a opacidade das palavras e a realização de transposições lexicais ${ }^{56}$. Este último

cada hũus perteecem, som tornados assy sem proveito (...) E pera tirar tal erro, os moços de seer enssynados logo de começo a leer e a escrever e a falar latym, contynuan/do a leer boos livros per latym e linguagem de boo encamynhamento per vyda virtuosa."

52 Refiram-se o estudo de Maria Helena da Rocha Pereira, "Helenismos no Livro da Virtuosa Benfeitoria", Biblos 57 (1981), 313-358 e as introduções de Joseph Piel às edições do Livro dos Oficios de Marco Tullio Ciceram..., (Coimbra: por ordem da Universidade, 1948), e do Leal Conselheiro (Lisboa: Bertrand, 1942).

53 Ivo CAstro, “A elaboração da Língua Portuguesa no tempo do Infante D. Pedro, Biblos 59 (1993), 97-106. É de notar o modo como o estudioso se pronuncia acerca do papel dos infantes de Avis na elaboração da língua portuguesa do século XV.

54 Em relação às vogais em hiato, refiram-se, por exemplo, "ceeos","periigos", "spirituaaes", "maao", "leõões", "saa”, "seer". A representação da nasalidade foi também responsável por uma grande oscilação gráfica: "nõ", "estando", “cidadãão", “en”, "ortelam."

55 É o caso de obsecração, que surge em Infante D. Pedro e Verba, Livro, III, cap. XII, 221: "primeiramentee se façam obsecraçoões, a que podemos chamar subpricaçoões em nossa linguagem."

56 Infante D. Pedro e Verba, Livro, I, cap. XVIII, 50: "E, segundo diz Sam Thomas en o primeiro livro da Soma moral, os prazeres som deleytaçoões somente possuydas per juizo razoavel, os quais se fazem largueza en o coraçom, chamamse em latim 'leticie', 
aspecto, particularmente notório no campo da tradução, detecta-se no uso de circunlóquios e de paráfrases nas obras dos Príncipes de Avis, bem como através da leitura de prólogos e da correspondência trocada entre Vasco Lucena e D. Pedro ${ }^{57}$. Na trasladação do De officiis de Cícero, o Infante revela que a maior acessibilidade do texto justifica a árdua tarefa:

"E esguardando eu como todo bem quanto a mais presta tanto he melhor, e nom embargando que o latim na christandade he mais geeral que o portugues, em Portugal esta linguagem he mais geeral que o latim, por aproveitar ao[s] portugueses amadores de virtude que nom som ou ao diante nom forem latinados, Eu me depus ao trabalho de tornar este livro em nossa linguagem." 58

Empenhados na divulgação de Cícero e de Séneca, os filhos do Mestre de Avis não podem ser dissociados dos estudos de recepção dos autores clássicos na Idade Média portuguesa ${ }^{59}$, nem tão pouco esquecidos na análise da ingente libertação da sintaxe, marcada por períodos longos, e da progressiva coloração portuguesa dos textos ${ }^{60}$. Assim se vê o à-vontade com que D. Pedro traduz histriones por "jograres" e poematibus por "trobas", a

que quer dizer 'ledices' (...) ordenar festas de gram fama, taaes prazeres como aquestes chamamse em latim specialmente 'jocunditates'. E nós, por non termos en nossa linguagem vocabullo apropriado, podemolos chamar 'sobreavondante e stremada alegria."

57 Reveste-se de particular interesse o Prólogo de Vasco de Lucena ao De Senectute, Apud Livro dos Oficios, XLV: "a minha trasladação não guardarà aquella duçura nem dignidade de eloquencia que há no latim, emperoo porque [v]os praz de lerdes por livros de lingoagem, por aproveitardes a muitos me trabalhei de o trasladar, nam porque o livro seja mais doce, mas porque seja mais commum, ca certamente o pequeno bem milhor he que o bem singular, e em isto não tirei letra, de letra, que seria trasladar, nem sentença de letra, que seria glosar, mas tirey sentença de sentença, que he bem e proveitosamente interpretrar".

58 Infante D. PEDro, dedicatória a Livro dos Oficios, 1-2. Sobre esta obra e o interesse de D. Pedro pelas leituras ciceronianas, leiam-se as considerações de Maria Helena da Rocha Pereira, em "Nas origens do Humanismo ocidental: os tratados filosóficos ciceronianos", Revista da Faculdade de Letras, II Série, vol. 2, (1985), 7-28.

59 Nair de Castro SoARes, em "O Infante D. Pedro e a cultura portuguesa", Biblos 78 (2002), 111, destaca também a importância de "D. Alonso de Cartagena, tradutor de Cícero, que, por ocasião da sua permanência diplomática em Portugal, entre finais de 1421 e início de 1423, dedica ao nosso rei D. Duarte a tradução do De inventione, inacabada, e um Memoriale virtutum, baseado na Ética de Aristóteles."

$60 \mathrm{O}$ mérito da tradução do Infante D. Pedro é sobejamente enfatizado por Joseph Piel, no estudo introdutório ao Livro dos Oficios, XXXVII: "o Livro dos Ofícios vem a ser um documento interessante da crise em que a Língua se encontrava no momento da transição entre a Idade Média e o Renascimento, quando se vê constrangida a satisfazer as exigências não só de novos géneros literários, como ainda de um novo ideal de civilização." 
relativa dificuldade em importar a palavra república ${ }^{61}$ ou em captar os traços semânticos de decorum" 62 . Na sua Vertuosa Benfeytoria, obra "perteecente pera os principes e grandes senhores", o Infante não deixa de referir certa carência vocabular da língua, escolho que está longe de ser um pretexto para, em co-autoria com João de Verba, escrever o seu tratado, recorrendo a nomes e a obras de referência, ainda que em segunda e terceira mão. A clareza e a simplicidade seriam, segundo o Infante D. Pedro, o garante do poder de generalização do texto ${ }^{63}$. Assim, a frase curta vinha em auxílio de uma melhor compreensão das ideias e a elegância ${ }^{64}$ complementava a estrutura escolástica e o confronto de pontos de vista organizados a partir da enciclopédia de Frei João de Verba.

Ciente da importância de verter para português obras escritas na língua do Lácio, D. Duarte recorre ao "símprez rimanço, por se melhor poderem reteer" ${ }^{65}$ as ideias que explana, não esquecendo que, apoiando-se em diferentes níveis cognitivos, delineara quatro tipos de homens, ou seja quatro perfis de possíveis leitores, no capítulo VIII: "de pequeno entender e saber"; de "grande entender e saber"; "algũus que som de curto entender e saber mas teem as vontades todas justas e dereitas"; os de "mui grande e sotil entender". O desvelo pela sua língua impelia-o até a escrever um capítulo

61 Saul Gomes sublinha em "«República»”, o carácter inovador do vocabulário da Vertuosa Benfeytoria, nomeadamente no uso do nome príncipe. Sobre o uso de 'república', o historiador acrescenta que o Infante o utilizaria "em contexto predominantemente erudito e histórico" (88), até porque o "conceito «República» circulava erudita e muito comedidamente na Corte portuguesa do tempo". (92)

62 Infante D. Pedro, Livro dos Oficios, cap. 33, 57: "E em este logar perteece de sse fallar daquello que em latim se chama «decorum», e em grego «prepom». E em esta linguagem que podemos dizer «fremosura das obras»". Só no capítulo 46 é que o tradutor usa decoro, provavelmente para evitar a repetição do nome "fermosura": Do decoro acerca da fremosura e ordenança e guarnimento dos ofícios."

63 D. Pedro e Verba, prólogo do Livro, 4: "foy a obra composta pera o engenhoso e sotil achar delectaçom a seu entendimento, e ao simprez porem non minguasse atal clareza per que aprender podesse as cousas que a elle convem, e tambem aquelles que filham prazer em novas maneyras de curto fallar achassem hi algũu comprimento do que em esto quer o seu desejo, e os que chãao fallam e querem ouvyr achassem scriptura segundo seu geyto."

64 A graciosidade literária de algumas imagens da Vertuosa Benfeytoria, atribuídas à pena de $\mathrm{D}$. Pedro, é já conhecida. Vejamos, apenas a título de exemplo, dois casos: "E vestindo o rostro de gracioso prazer, mostraremos ledice do nosso coraçom aaquelle de que duvidamos o que ha de pedir." (Livro II, XXX, 170). E, no Livro VI, III, 319: "E, prantando arvor em area leve, que com pouco vento asynha se rynca, sobre a pedra sem çumo espargem semente, spalhando benefficios e nom outorgando, pois nom podem dar fruyto, por bem que lhe façam."

65 D. DuARTe, Leal, XXXIX, 150. 
sobre os mais correctos procedimentos de tradução para linguagem ${ }^{66}$, apesar de revelar pouca mestria pessoal nesse campo específico, de acordo com o veemente parecer de Joseph Piel ${ }^{67}$.

Muito embora estas obras visassem um público alargado, permanecem ligadas a um círculo culto minoritário, materialmente favorecido e em condições de colocar em prática os ensinamentos aí veiculados ${ }^{68}$.

A filosofia em língua portuguesa assume então, no período medievo, por um lado, carácter proactivo em estreita ligação com exigências governativas. Não esqueçamos que uma das principais vias de entendimento da função da filosofia havia sido, aliás, transmitida pelo Infante D. Pedro, ao transpor a prosa ciceroniana para linguagem:

"Qual he a cousa que per deos avemos que seja mais de desejar que a sabedoria; que he mais digna ao homem? Aquelles que esta desejam som chamados phillosofos; por que nom he outra cousa philosofia, se a tu quiseres entrepetar, senom estudo de sabedoria (...) ho estudo da ssabedoria (...) sempre busca cousas que perteeçam e valham pera viver bem e bem-aventuradamente. E sse hi ha algũa razom per que acalcemos a firmeza das virtudes, ou he per esta arte, ou nom ha hi outra per que o possamos acalçar ${ }^{69}$."

Por outro lado, assomam matizes de afectividade e de cristalina devoção que associam a res filosófica à espiritualidade e à vivência pessoal do sentimento religioso. A comparência do Orto do Esposo, do Rosal d'Amor ou do Estimullo Amoris nas bibliotecas pessoais dos filhos de D. João I atesta essa dupla valência.

\section{De uma espécie de análise à íntima "apagada e vil tristeza" a uma teoria do bem comum}

Se por entre as páginas do Leal Conselheiro encontramos capítulos sobre a tristeza e as diversas vertentes do amor ${ }^{70}$ que nos mostram como da

66 Vd. Sebastião Tavares de PINHo, "O triplo código do tradutor de latim: do Leal Conselheiro aos nossos dias", Mathésis 2 (1993), que sintetiza as três vias da seguinte forma: "Traduzir tudo, traduzir só e traduzir tal como o que está no original."

67 Cf. Joseph PIEL, introd. a Livro dos Oficios, XXVII-XXVIII.

68 D. Pedro e Verba, Livro, I, cap. III, 17: "aaquelles he mais perteecente a ensinança que son melhor despostos a usar do que aprendem (...) Semelhavelmente, porquanto os principes son possuydores das riquezas temporaaes de que a muitos podem fazer bem e mercees, mostrasse que elles tẽe melhor desposiçom pera usar daquela douctrina que os outros homẽes, os quaes ainda que a saybham e queyram poer em obra, per costrangimento da mingua cessam de fazer o que desejam."

69 Infante D. Pedro, Livro dos Oficios, Prólogo, Livro II, 97.

70 Mário Martins, “A amizade e o amor conjugar no «Leal Conselheiro»”, Didaskalia 
brevidade do verso cortês se conseguiu talhar uma prosa reflexiva, mais interessante ainda se afigura o psicologismo avant la lettre e a capacidade de autoanálise experimentados pelo rei. Talvez se pudesse, com base neste escrito de $\mathrm{D}$. Duarte, dar uma resposta afirmativa à possibilidade de existir o género autobiográfico na Idade Média ${ }^{71}$. São vários os capítulos dedicados ao "menencorico" sentimento nem sempre negativo, já que se afigura raiz problematizadora de algumas das nossas principais obras de ascética:

"A tristeza do segle obra morte, mas aquela tristeza que obra peendença stavel pera a saude, obediente é, graciosa, humildosa, mansa, suave, paciente, assi, como aquela que descende de Deos e se estende e oferece a toda door do corpo e do spritu sem cansaço, por desejo de perfeiçom ${ }^{72}$."

Quando conduzido à via do contemptus mundi - presente no Orto do Esposo, no Boosco Deleytoso, no Virgeu de Consolaçon ou nas Coplas do Condestável - este humor furta-se, pois, à esterilidade, gerando uma atitude de aperfeiçoamento interior e de desprendimento terreno. Nela pensaria D. Duarte, ao contemplar no seu escaparate a Bíblia e o Orto ou ao aduzir um excerto da Vita Christi no seu "ABC da Lealdade", obras em que se verifica a vitória da fé sobre a filosofia racional ${ }^{73}$.

Oferecendo-se como caso de estudo, o monarca confessa a sua tristeza humanal, os sintomas que lhe estão associados, bem como o poder curativo da esperança em Deus e da força de vontade ${ }^{74}$. O ócio intelectual, o exercício físico e a companhia de "sages amigos" complementam a prescrição terapêutica que uma indagação pessoal (mais do que médica) iluminou. Quão distantes estamos já da estereotipada "coita" de amor, fingida e forjada em ardilosos versos, que se manifesta pela ausência do amado, pela negação da recompensa ou pelo obstáculo de última hora que impede o encontro. Ao enunciar "as maneiras d'amar", inspirado pelo "livro de Tulio"75 ("benque-

9 (1979), 269: "De facto, no Leal Conselheiro, guião cristão dum leigo para leigos, o rei deixa-nos entrever a complexidade enorme do amor conjugal, mistura de várias espécies de amor...".

71 Quem formula a questão é P. ZumThor no artigo “Autobiographie au Moyen Age?" inserto em Langue, Texte, énigme (Paris: Seuil, 1975), 165-180.

72 D. Duarte, Leal, XVIII, 70.

73 D. Duarte, Leal, CIII, 374: "E pera guardar esta lealdade acerca de Nosso Senhor, o mais que tenho em este trautado scripto esto conselha, ensina e avisa; ca eu mesturo moral filosafia, de que algũa parte vi, com seus mandados e dictos dos sanctos e catolicos sabedores, que a mais perfeitamente que os filosafos entenderom...".

74 Vd., sobre este aspeto, Maria Cândida PACHeCo, "Intelecto prático e vontade em D. Duarte, rei de Portugal", Revista da Faculdade de Letras - série de Filosofia 12-13 (1995-96), 33-42.

75 D. Duarte, Leal, RIIII, 171. 
rença", "desejo de bem-fazer", amores, e "Amizade"), D. Duarte recomenda o afastamento do amor cego e incorrespondido e fala desenvolvidamente das dimensões conjugal e filial do sentimento amoroso. Nesta filia, que progressivamente se alarga e alcança a esfera pública, o passo seguinte radica na causa comum e nas obrigações políticas.

Já o seu irmão D. Pedro escolhe como tema central do Livro da Vertuosa Benfeytoria o bem-fazer ${ }^{76}$, vertente que sobrepõe à dimensão fisiológica da dor e à análise individual, numa relação de poder baseada na solidariedade e que, em última instância, recorda as ligações vassálicas ${ }^{77}$. O amor filial votado aos progenitores ${ }^{78}$, a amizade ${ }^{79}$ ou as relações de leal serviço e colaboração são viáticos da medicina da alma, voltada para o cuidado do outro ${ }^{80}$, ultrapassando-se o cuidar e suspirar dos trovadores, ainda que o Infante não se prive de contar, quase em confidência, o episódio em que a sua ama lhe explica que nem todos os pedidos são admissíveis ${ }^{81}$. É nesta linha de balsâmica ligação entre benfeitor e favorecido que se define o fundamento do conceito-chave da obra: aqueles [benefficios] faram sãas as feridas e consolaram os dampnos daqueles que parecerem perdidos 82 ." A tristeza funciona, então, como uma obstrução à intrepidez voluntariosa, por isso deve banir-se a todo o custo ${ }^{83}$, sob pena de propiciar um ensimesmamento abúlico.

O Infante apoia-se na filosofia antiga e atribui a Platão dois preceitos muito importantes: "hũu soo cuydado devem ter os principes, convem a

76 D. Pedro e Verba, Livro, I, VII, 26: "Beneficio he affeyçom vertuosa de proveytar a outrem, mostrada per obra. (...) beneficio he bem feyto a outrem com entençom de lhe prestar".

77 Sobre o lastro semântico de determinados vocábulos do feudalismo e as suas repercussões nas relações humanas, $V d$. José MATtoso, “A difusão da mentalidade vassálica na linguagem quotidiana”, in: Em torno da Idade Média, coordenado por Helder GodinHo (Lisboa: Universidade Nova de Lisboa, 1989), 205-223. Na Vertuosa Benfeytoria, há reminiscências da triádica sociedade feudal quando se afirma que "o principal membro da nossa comunydade he o stado ecclesiastico e dos oradores...". (II, XVI, 106) Além disso, no código de agradecimento ao benfeitor, alguns dos gestos aconselhados aproximam-se dos ritos feudo-vassálicos, nomeadamente IV, II, 236-237.

78 D. Pedro e Verba, Livro, II, XIX, 120-122.

79 D. Pedro e Verba, Livro, II, XVII, 112-113. O tema interessa à Dinastia de Avis, sob cujos auspícios se terá traduzido o De Amicitia. O tratado ciceroniano voltará a suscitar uma tradução portuguesa no século XVI. Sobre o assunto, vd. Jorge OsóRIo, "Duarte de Resende, tradutor do «De Amicitia» de Cícero (1531)”, Humanitas 47 (1995), 721-737.

80 D. Pedro e Verba, Livro, II, XVIII, 114.

81 D. Pedro e Verba, Livro, III, XIII, 227.

82 D. Pedro e Verba, Livro, II, XXXI, 177.

83 D. Pedro e Verba, Livro, III, XI, 219: "O quarto tempo em que sse nom deve requerimento fazer quando os senhores stam manancorios ou tristes (...) porque toda voõtade requere ledice..." 
saber, sguardar em todas suas obras o proveito dos subdictos e squeecer os proprios desejos. Outro mandado he que per tal maneira curem eles o corpo da comũydade que, en dando saude a hũa parte, nom desamparem a todo ${ }^{84}$."

Entre os "puramente auctivos" e os "sotiis speculativos", os príncipes ocupam, segundo o Infante, uma posição intermédia que os responsabiliza socialmente, porque, pelo seu estatuto, têm o dever de cultivar a filosofia prática para orientarem melhor as suas acções políticas. Na dedicatória da obra, D. Pedro elogiava o irmão, afirmando que, ao ler este tratado, D. Duarte se veria ao espelho, estando ali implicitamente retratado pelas suas "boas obras". Não se podia vislumbrar maior fidelidade ao espírito e à letra da literatura de espelhos de príncipes, reveladora da "progressiva laicização do estado, facilitada aliás pela nova estrutura social, ocasionada pelas regalias e favores concedidos ao povo e pela ascendência à nobreza por mérito individual e dedicação à causa pública ${ }^{85}$."

A preocupação com o "cuydado do bem comũu" desliga o homem da sua condição singular ("o ben comũu he melhor que o personal"86) e converte as figuras do príncipe e do rei em cabeças da colectividade, que lêem e escrevem quer para autoconhecimento e reflexão das suas práticas, quer para esclarecimento e promoção do espírito crítico junto da classe social a que pertencem ${ }^{87}$. Independentemente da forma de expressão usada para abordar o tema, o fim a atingir com o benefício é unívoco ${ }^{88}$ e pressupõe uma intenção movida pelo "querer da voõtade" livre.

O interesse pelo alcance semântico da palavra intenção instiga os autores do tratado a apoiarem-se em várias fontes filosóficas. Mas, provavelmente este diálogo intertextual prende-se também com a necessidade de manejar alguns conceitos filosóficos que ainda não haviam sido pensados em língua portuguesa e que não vingariam de modo autónomo, isto é, pelo simples arroteamento de inseguranças discursivas ou pelas notórias marcas de circularidade explicativa. Vejamos:

84 D. Pedro e Verba, Livro, II, IX, 79.

85 Vd. Nair de Castro SoAREs, "A Virtuosa Benfeitoria, primeiro tratado de educação de príncipes em Português ”, Biblos 69 (1993), 295.

86 D. Pedro e Verba, Livro, II, XIV, 93.

87 D. Pedro e Verba, Livro, II, XXII, 133: “ a sabedoria e o real poderio sejam juntos en hũa persoa, e principe e sabedor todo seja hũa cousa. (...) nom he sabedor o que, por seer moor leterado, moor pode chilrar, mas o que em suas obras mais usa de razom."

88 D. Pedro e Verba, Livro, II, V, 67: "Ensinança nos dá Tulio, que antre os philosophos moraaes en bem falar tem frol graciosa, e diz que a vertude e honestidade son desvayrados nomes e a cousa per eles significada he hũa." 


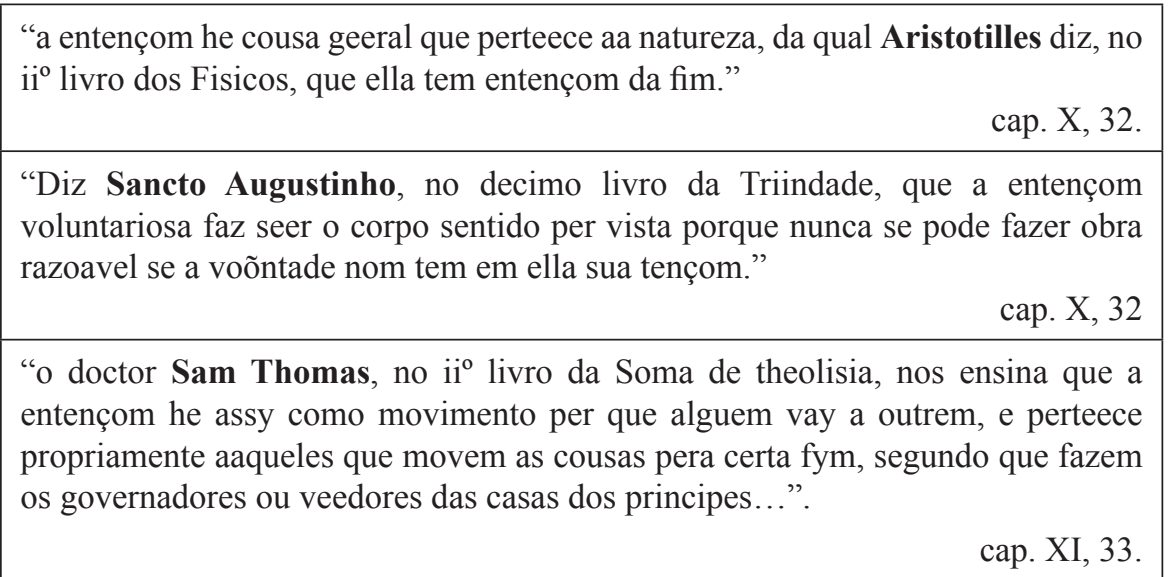

Os autores sentem a premência de consultar as auctoritates diante dos leitores não tanto para corroborarem as suas afirmações, mas para desenvolverem um pensamento consistente em vernáculo, a partir de boas matrizes latinas ou (no caso do Estagirita) recebidas por via latina. Daí que o filosofema vontade mereça um maior suporte teórico, vindo a lume o nome de autores clássicos:

“... aprendamos que diz Aristotilles, no iii ${ }^{\circ}$ livro da Alma, que a voõtade he movedor per outrem movido. E pera sse mostrar aquesta conclusom saybhamos que no ii $^{\circ}$ livro dos Fisicos he scripto que a arte aa qual perteece a fym move per seu mandado as artes que trabalham em os meyos per que a ffym hade ser gaaçada. (...) E portanto he scripto no primeyro livro da Policia que a voõtade move per seu mandado os poderios deffensor e desejador, os quaes lhe obedecem, nom como servos em constrangida sobjecçom, mas segundo homẽes livres en obedeẽça desejosa..." ${ }^{\text {"89. }}$.

e a evocação do Evangelho, num retorno às Epístolas de $\mathrm{S}$. Paulo (Rom. 2), em consonância com o respeito pelo coro de vozes a reunir numa obra de cariz filosófico que não abdica da sensibilidade cristã ${ }^{90}$.

Esta aliança política e moral, que corresponde a um dos "stados do mundo" e se traduz num compromisso dos poderosos perante a sociedade que re-

89 D. Pedro e Verba, Livro, II, III, 61-62.

90 Até porque este enquadramento jurídico do modelo social é cabimentado pela lei cristã, segundo se lê no Livro, II, XVI, 104:"A obediência per que os sobjectos son ordenados aos principes he mais firme antre os christaãos, per aazo da fe, que antre as outras gentes, e os que as bem guardam merecem galardom spiritual." 
gem ${ }^{91}$, encerra uma "ética de funcionalismo laico" 92 informada pela cultura política emergente, particularmente interessada em colher os ensinamentos sistematizantes de Aristóteles, de Egídio de Roma e de Tomás de Aquino.

Se o pecado acarretou consigo a sujeição do ser humano, vai sendo tempo de os governantes subverterem o estado de "temporal senhorio"93 que lança n" $[\mathrm{o}]$ cativeyro" a alma ${ }^{94}$ e a entorpece. Nesse caso, uma atitude voluntariosa afigurar-se-á resgatadora (porque a "alma e a voõtade he livre e poderosa sobre seu querer, en tanto que nom pode seer retehuda em este carcer en que he çarrada" 95 ), contrariando-se a funesta circunstância de o homem ser "morador em aquella parte que a desvayradas mudaçoões jaz sojugada" 96 que o vulnerabiliza e explica a consolidação de laços entre estratos sociais diferentes.

Assim, a penúria sentida pela queda humana pode ser revertida através de uma política governativa ciente dos seus deveres para com os cidadãos ${ }^{97}$ e até de uma formação mais sólida ${ }^{98}$, proposta que a Carta de Bruges apresentava abertamente. Nesta demanda de resgate ontológico, o estatuto da filosofia sai reforçado, porque, se foi graças a ela que "o emperio de Grecia cobrou o mundo" 99 também é pela via filosófica que os príncipes podem aceder aos mais valiosos conhecimentos. A "politica comunidade" que une os homens num corpo social fortalecido por laços de interdependência exige mentes bem formadas, daí que a sensatez e os conselhos morais de Séneca ("que antre os moraes philosophos tem o principado"100) ou de Túlio Cícero sejam inspiradores para a Casa de Avis ${ }^{101}$.

91 Como nos mostra Humberto Baquero Moreno, em "O Infante D. Pedro e o ducado de Coimbra", Revista de História 5 (1983-84), o Infante era bastante solícito na resolução dos problemas políticos e económicos do seu ducado, provando que as suas acções espelhavam as convicções veiculadas nos escritos saídos da sua pena.

92 SoAres, “A Virtuosa Benfeitoria", 290.

93 Infante D. Pedro e Verba, Livro, II, XVI, 102.

94 Infante D. Pedro e Verba, Livro, II, XVI, 103.

95 D. Pedro e Verba, Livro, II, XI, 85. É na Transcendental philosofia que se reforça a distinção entre as duas condições: "he chamado livre [o homem] que (...) he e faz suas obras por sy meesmo."

96 D. Pedro e Verba, Livro, IV, I, 231.

97 D. Pedro e Verba, Livro, III, IV, 196-197: “O ii stado daquesta vida he moral, e em elle poderom os homẽes bem viver se vertuosamente perseverarom em a dereytura original que na criaçom hes foy outorgada, mas, porque, desobedecendo a Deus, forom pecadores, nasceo antre elles tal desordenança per que a policia do mundo ligeyramente perecera se o stado cavaleyroso dos reys e dos princepes e dos outros senhores a nom governara."

98 D. Pedro e Verba, Livro, II, XXII, 134.

99 D. Pedro e Verba, Livro, II, XXII, 134.

100 D. Pedro e Verba, Livro, I, IV, 20.

101 Matos, "A presença", 261: "Nos séculos XIV e XV foram dados passos deveras significativos no tocante à restituição de textos de autores clássicos que, até aí, ou 
No seu estudo sobre o tema da amizade em sede estóica, Banateanu salienta que o autor do De officiis "fait descendre la morale du niveau du cosmos au niveau de l'homme et réinscrit les fondements de la loi morale dans le cadre de la communauté humaine. (...) Cicéron opère donc un glissement du théorique au pratique, et ramène toute la philosophie à l'action ${ }^{102}$." $\mathrm{Na}$ verdade, a adesão às premissas da moral desenvolvida pelos estóicos diz muito sobre as preocupações ético-políticas que assaltam a nossa realeza, como se deduz pelas palavras de D. Pedro e João de Verba:

"Mayor perfeiçom he governar moralmente a comunydade, que fazer e prantar vinhas e agros, porque os regedores moraaes soportam as vertudes em as almas e os lavradores da terra manteẽ as compreyssoões em as persoas, as quaaes ligeyramente pereceriam se com dereita policia nom fossem regidas ${ }^{103 . "}$

Em causa está a manutenção de uma ordem que o príncipe virtuoso e esclarecido assegura em prol do bom funcionamento da comunidade. A grei pode zelar, em parte, pelo estado natural do mundo dependente dos "continuados movimentos de geeraçom e de corrupçom" 104 , mas a dimensão política e moral depende de uma "boa governança" e de relações de lealdade, de entreajuda e gratidão entre o senhor e os súbditos, já que "[g]lorioso he o reyno em que o louvor do poboo he testemunha do boo senhorio" 105.

\section{Três gerações: uma mesma matriz literária}

“... yo do por respuesta aquello que el moral Seneca al / su Luçilio escriue: Yo fablo - dixo el - contigo / de la comun enfermedat, assi como aquel que / jase contigo de vna dolencia mesma e tracto / contigo de los remedios, e por tanto oyeme assi como si yo fablasse apartada e se /cretamente a mi mesmo ${ }^{106}$."

não se conheciam (pura e simplesmente); ou se conheciam truncados; ou se conheciam, nalguns casos, em versões adulteradas ao nível de uma recriação inventiva ou, mesmo, ficcionada. Alguns intelectuais desse período empenharam-se, de uma forma consciente, em encontrar testemunhos de textos dos autores clássicos mais lidos e procurados pelo brilhantismo das suas ideias."

102 Anne Banateanu, La théorie stoïcienne de l'amitié. Essai de reconstruction (Paris: Éditions du Cerf, 2001), 10.

103 D. Pedro e Verba, Livro, III, IV, 197.

104 D. Pedro e Verba, Livro, II, X, 82.

105 D. Pedro e Verba, Livro, II, XXIV, 139.

106 Condestável D. Pedro, Coplas, 114. 
Sem sabermos se o tom panegírico de Fernão Lopes empola a acção literária de D. João I, uma vez que nas entrelinhas do discurso do cronista que imortalizaria a Casa de Avis vinha à tona um processo de mitificação governativa da Ínclita geração, é certo que ela contribui muito significativamente quer para a dignificação da língua portuguesa e para o seu enriquecimento lexical, quer para a cultura literária, mormente filosófica, em meio áulico.

Através do Livro de Montaria, o Mestre de Avis procura tratar de um assunto um pouco marginalizado ${ }^{107}$ e partilhar com os seus pares o gosto por uma arte que, além de prazenteira, funcionaria como treino para o exercício das armas. Já nesse escrito encontramos, logo no primeiro capítulo, interesse em destacar a importância do entendimento e da vontade, na qualidade de bússola orientadora da personalidade, ideia que as obras dos seus dois filhos mais velhos subscrevem e aprofundam.

Arredada a hipótese de D. Henrique ser o autor da tradução do Secretum Secretorum ${ }^{108}$ de Pseudo-Aristóteles, obra que constava do acervo de D. Duarte ${ }^{109}$, ainda assim não é escamoteável o lugar de primeiro plano ocupado pelo Infante de Sagres na renovação da Universidade portuguesa e na atribuição de novos mundos ao Mundo pelo seu empenho na odisseia das Descobertas.

O saber, a curiosidade intelectual, o cultivo da leitura e da escrita definem a Dinastia de Avis, representada nestas linhas sobretudo por D. Duarte, pelo seu irmão D. Pedro e pelo malogrado Condestável, mas sem que se

107 D. Jỗo I, Livro da Montaria feito por D. João I, Rei de Portugal, ed. de Francisco M. E. Pereira (Coimbra: Imprensa da Universidade, 1918), 3: "Porem nos vendo em como o joguo de andar ao monte era tam bõo, e tam proveitoso, que em sua bondade passa todollos joguos, a que ora dizem manhas, e em seu seer, pera ser os homẽes por elle poderem aproveitar mais que de nenhum dos outros de que os homẽes agora usam; e assi mesmo em como elle era em si mais alta cousa e mais proveitosa que algũas outras, de que se algũus trabalharam de fazer livros, assi como de Falcoaria, e de Cantigas, doutras cousas e artes que muyto menos que esta aproveitam; e nos vendo assi tam boa cousa, que he usada dos bõos e grandes, estar desprezada; e porque a nosso veer nom foi nenhum, que se della trabalhasse fazer livro, e como pollos livros que eram feitos se nom podessem mostrar as perfeiçoões que em ella a, nem outrossi que dessem ensino a aquelles, que ouvessem sabor de serem monteyros, em como o poderiam melhor seer, e assi mesmo em como se podessem guardar de algũas coisa...".

108 Pseudo-Aristóteles, Segredo dos Segredos, introd. e ed. de A. Moreira de Sá (Lisboa: Faculdade de Letras, 1960). Contribuiu para a desmistificação da tese segundo a qual esta tradução se devia a D. Henrique o Professor Joaquim de CARvalHo no artigo "O «Secreto de los secretos de astrologia» do Infante D. Henrique (rectificação)", $O$ Instituto 93 (1938), 345-357.

109 Vd., sobre a relação de D. Duarte com a astrologia, Luís Albuquerque, "A astrologia e Gil Vicente", Estudos de História (Coimbra: Por ordem da Universidade,1974, vol.1), especialmente 7-14. 
possa omitir o nome nem a responsabilidade de D. João I e de D. Filipa de Lencastre no fulgor cultural alcançado.

Nas suas bibliotecas (ou melhor nas informações que delas nos restam) vislumbramos interesses bibliográficos comuns, a mesma admiração por Cícero e por Séneca, o repetido gesto de revisitação do legado clássico e o respeito pela língua materna. Não só a "moral philosophia" é "provechosa a la salud de / la anima" podendo chamar-se "san/cta sabiduria"110, como nela a Casa de Avis encontra o instrumento reflexivo e didactizante mais adequado para os cortesãos se pensarem a si próprios, às suas circunstâncias pessoais de vida, e às avisadas práticas de soberania e de bem comum. A filosofia encerra um modus vivendi que dispõe a alma para a virtude e ilumina os homens através da razão. Porém, entre nós, a partir do século XV, requer-se um maior poder de generalização para que os seus ensinamentos se tornem verdadeiramente eficazes: "nom embargando que o latim na christandade he mais geeral que o portugues, em Portugal esta linguagem he mais geeral que o latim"111. Não admira, por isso, que a sabedoria antiga tenha de ser pensada em linguagem, num esforço de reconceptualização do mundo e de dotação de novas aportações a determinadas áreas semânticas e lexicais do português - pensemos no domínio da política, da ética, do direito e da economia.

Insistimos, por isso, para vindouros trabalhos de fundo, que tais escritos filosóficos estão prenhes de elementos importantes para se analisar o amadurecimento da língua enquanto instrumento pensante, em níveis de progressiva complexidade e de constante enriquecimento lexical.

$* * *$

\section{Que filosofia?}

O problema da filosofia portuguesa insere-se no problema mais lato da autonomia do pensamento, e da língua em que se cria...

Afonso Botelho

Não parece sensato, e está longe de ser original, insistir na questão da filosofia portuguesa. Talvez dê, no entanto, alguns frutos o exercício que relacionar a autonomia do pensamento com a língua que lhe dá expressão, isto é, aquele que colocar em perspectiva o modo de funcionamento de uma atitude filosófica em língua portuguesa nos seus primórdios. Como se pro-

110 Condestável D. Pedro, Coplas, 74.

111 D. Pedro, dedicatória a Livro dos Oficios, 1. 
cessa a emancipação do português face à língua latina, reconhecidamente filosófica e com prestígio científico internacional ao longo de toda a Idade Média? De que forma se transita de uma língua poética, com provas dadas nos cancioneiros galaico-portugueses para um idioma capaz de se apropriar de conceitos fundamentais existentes nos escritos filosóficos clássicos e de finalmente produzir um pensamento próprio?

Para respondermos a estas questões, provavelmente não precisamos de mergulhar na problemática das filosofias nacionais que Afonso Botelho convoca. O acompanhamento do processo de autonomização de uma língua vernácula também é uma forma legítima de pensar a filosofia e as suas formulações autóctones, evitando, todavia, no estudo das relações entre a língua e a filosofia em Portugal, expressões como alma portuguesa, espírito lusitano ou génio português.

Mais do que classificar a suidade de D. Duarte como intraduzível, ou pelo menos antes de o fazer, valerá a pena regressar à época em que a palavra surge, ao exacto momento em que El-rei sente necessidade de a utilizar para especificar uma dimensão psicológica da sua anatomia da melancolia. Situemo-nos, então. Depois de elencar várias paixões, numa lógica bastante próxima à da segunda parte das Collationes (De octo principalium vitiorum remediis) ${ }^{112}$, o filho mais velho de D. João I discorre sobre o "humor menencorico", apoiando-se fielmente nas definições de tristeza de João Cassiano, traduzidas quase à letra, como podemos constatar numa breve leitura comparativa $^{113}$ :

112 Vd. João Cassiano, Collationum XXIV Collectio In Tres Partes Divisa, in Patrologia Latina editada por J.-P. Migne, (Paris: 1846, vol. 49), Pars I, V, sobretudo o cap. II, col. 611: "Octo sunt principalia vitia, quae humanum infestant genus, id est, primum gastrimargia, quod sonat ventris ingluvies; secundum fornicatio; tertium philargyria, id est, avaritia, sive amor pecuniae, quartum ira; quintum tristitia; sextum acedia, id est, ansietas, sive taedium cordis, septimum cenodoxia, id est, jactantia, seu vana gloria; octavum superbia." Doravante citadas pela abreviatura Coll.

113 A modesta leitura comparativa que aqui realizamos presta-se apenas a um trabalho circunscrito com o vocabulário psicológico e filosofante de D. Duarte. Para um estudo profundo e sistemático sobre as relações entre o fundador do monaquismo ocidental e o nosso Rei, $v d$. João Dionísıo, D. Duarte, leitor de Cassiano (Dissertação de Doutoramento em Literatura Portuguesa apresentada à Faculdade de Letras de Lisboa, 2000). 


\begin{tabular}{|c|c|}
\hline João Cassiano & D Duarte, Leal Conselheiro ${ }^{114}$ \\
\hline $\begin{array}{l}\text { Tristitiae genera sunt duo: unum, quod vel } \\
\text { iracundia desinente, vel de illato damno ac } \\
\text { desiderio praepediyo cassatoque generatur; } \\
\text { aliud, quod de irrationabili mentis } \\
\text { anxietate seu desperatione descendit. } \\
\text { Coll., Pars I, V, cap. XI }{ }^{115} \text {. }\end{array}$ & $\begin{array}{l}\text { "E diz que som duas maneiras de tristezas. } \\
\text { Ũa que vem e procede de virtude. Outra } \\
\text { de pecado. E aquesta que vem de pecado } \\
\text { departe em outras duas deferenças. } \\
\text { Ũa que fica depois que se parte a sanha, } \\
\text { por a perda que recebe, ou por o desejo } \\
\text { que nom comprio. A outra nace d'algũu } \\
\text { queixume sem razom que está na voontade, } \\
\text { ou descende da desperaçom." }\end{array}$ \\
\hline $\begin{array}{l}\text { Est etiam aliud detestabilius tristitiae } \\
\text { genus, quod non correctionem vitae, } \\
\text { nec emendationem vitiorum, sed } \\
\text { perniciosissimam desperationem animae } \\
\text { injicit delinquenti. Quod nec Cain fecit } \\
\text { post fratricidium poenitere, nec Judam } \\
\text { post traditionem ad satisfactionis remedia } \\
\text { festinare, sed ad suspendium laquei sua } \\
\text { desperatione pertraxit. } \\
\text { Inst., IX, cap. IX }{ }^{116} \text {. }\end{array}$ & $\begin{array}{l}\text { "E declara que há i ũa geeraçom de } \\
\text { tristeza a qual nom traz à alma do pecante } \\
\text { correiçom de vida, nem emmenda dos } \\
\text { pecados, mas mortal desperaçom, a qual } \\
\text { nom leixou Caim fazer peendença depois } \\
\text { do homecidio, nem a Judas depois da } \\
\text { treiçom buscar caminho de satisfaçom, mes } \\
\text { trouxe-o a seer pendurado em laço." }\end{array}$ \\
\hline $\begin{array}{l}\text { Ideoque utilis nobis una re tantum tristitia } \\
\text { judicanda est, cum hanc vel poenitudine } \\
\text { delictorum, vel desiderio perfectionis } \\
\text { accensi, vel futurae beatitudinis } \\
\text { contemplatione concipimus. De qua et } \\
\text { beatus Apostolus: Quae secundum Deum } \\
\text { est, inquit, tristitia, poenitentiam ad } \\
\text { salutem stabilem operatur ; saeculi autem } \\
\text { tristitia mortem operatur (II Cor. VII). } \\
\text { Inst., IX, cap. X }{ }^{117} \text {. }\end{array}$ & $\begin{array}{l}\text { "E por em em esto a tristeza é de julgar } \\
\text { proveitosa, quando nos pesa dos pecados, ou } \\
\text { somos acendidos em desejo da perfeiçom, } \\
\text { ou quan/do concebemos a contemplaçom } \\
\text { da bem-aventurança que é por vĩir, da qual } \\
\text { diz o apostolo Paulo: Aquela tristeza que é } \\
\text { segundo Deos, obra peedença stavel pera a } \\
\text { saude. A tristeza do segle obra morte...". }\end{array}$ \\
\hline
\end{tabular}

114 D. DUARTE, Leal, XVIII, 70-71.

115 João CASSIANO, Coll., col. 627.

116 João CASSIANO, De coenobiorum Institutis Libri Duodecim, in: Patrologia Latina editada por J.-P. MIGNE, liber IX - De spiritu tristitiae, vol. 49, cols. 357-358. Doravante citadas por Inst.

117 João CASSIANO, Inst., col. 358. 
Sed illa tristitia quae poenitentiam ad salutem stabilem operatur, obediens est, affabilis, humilis, mansueta, suavis, ac patiens, utpote ex Dei charitate descendens, et ad omnem dolorem corporis ac spiritus contritionem infatigabiliter semetipsam desiderio perfectionis extendens, et quodammodo laeta ac spe profectus sui vegetata, cunctam affabilitatis et longanimitatis retinet suavitatem, habens in semetipsa omnes fructus Spiritus sancti, quos enumerat idem Apostolus: Fructus autem Spiritus est charitas, gaudium, pax, longanimitas, bonitas, benignitas, fides, mansuetudo, continentia (Galat. VII). Haec vero asperrima, impatiens, dura, plena rancore et moerore infructuoso, ac desperatione poenali, eum quem complexa fuerit $a b$ industria ac salutari dolore frangens ac revocans, utpote irrationabilis et intercipiens non solum orationum efficaciam, verum etiam universos, quos praediximus, fructus spiritales evacuans, quos novit illa conferre.

\begin{tabular}{|l|}
\multicolumn{1}{c}{ Inst., IX, cap. XI ${ }^{118}$} \\
\hline Quapropter absque illa quae vel pro \\
salutari poenitentia, vel pro studio \\
perfectionis, vel pro desiderio suscipitur \\
futurorum, omnis tristitia tam quam \\
saeculi, et quae mortem inferat, aequaliter \\
repellenda est, ac sicut fornicationis \\
spiritus, vel philargyriae, vel irae, de \\
nostris cordibus penitus extrudenda. \\
Inst., IX, cap. XII ${ }^{119}$
\end{tabular}

“... mas aquela tristeza que obra peendença stavel pera a saude, obediente, é graciosa, humildosa, mansa, suave, paciente, assi como aquela que descende de Deos e se estende e oferece a toda a door do corpo e do spiritu sem cansaço, per desejo de perfeiçom. E assi como leda polo seu proveito e recriada, retem toda graciosidade e afabilidade. E tem em si mesma todolos fruitos do sprito, os quaes conta o Apostolo, dizendo: caridade, plazer, paz, longaminidade, bondade, benignidade, fe, mansidõe, continencia. Mas esta outra é mui aspera, sem paciencia, dura, chea de rancor e choro sem proveito, e dá desperaçom penal.

E aquel que abraçar revogoo da industria saudavel e quebranto per door, asi como cousa sem razom, e faze-o antrepoer nom soo a eficacia da oraçom, mas ainda faz evacuar todolos fruitos spirituaes que dissemos...". "...os quaes a outra soube dar por a qual cousa fora daquela que é tomada, ou por pendença saudável, ou per studo de perfeiçom, ou por desejo das cousas que som de viir, toda outra tristeza assi como de morte é de guardar. E assi como ao spritu do fornizo ou de filarguia, que é avareza, ou da ira, de nossos corações de todo é de arrincar, assi ao sprito da tristeza ...".

118 João CASSIANO, Inst., cols. 358-359.

119 João CASSIANO, Inst., cols. 359-360. 


\begin{tabular}{|c|c|}
\hline $\begin{array}{l}\text { Hanc ergo perniciosissimam passionem ita } \\
\text { de nobis expellere poterimus, ut mentem } \\
\text { nostram spiritali meditatione iugiter } \\
\text { occupatam futura spe et contemplatione } \\
\text { repromissae beatitudinis erigamus. Hoc } \\
\text { enim modo universa tristiarum genera, } \\
\text { sive, quae ex praecedente ira descendunt, } \\
\text { sive quae de irrationabili mentis } \\
\text { confusione procedunt, seu quae lethalem } \\
\text { desperationem nobis inducunt, valebimus } \\
\text { superare, cum aeternarum rerum ac } \\
\text { futurarum intuitu semper laeti, atque } \\
\text { immobiles perdurantes, nec casibus deiecti } \\
\text { praesentibus, nec prosperis fuerimus elati, } \\
\text { utraque velut caduca et mox transeuntia } \\
\text { contemplantes. Inst., IX, cap. XIII }{ }^{120}\end{array}$ & $\begin{array}{l}\text { "Aquesta mui enganosa paixom assi de nós } \\
\text { fora lançar poderemos, se a vontade nossa } \\
\text { per spiritual cuidado continuadamente } \\
\text { ocupada a esperan/ça do que ha-de seer } \\
\text { a contemplaçom da prometida bem- } \\
\text {-aventurança levantarmos. Per aqueste } \\
\text { modo todalas geerações das tristezas, assi } \\
\text { as que d'algũa sanha passada descendem, } \\
\text { como as que da desarrazoada voontade } \\
\text { e concertada procedem, ou as que per } \\
\text { leixamento d'algũu ganço ou perda a } \\
\text { nós feita venhom, ou as que peçonhenta } \\
\text { desperaçom nos enduzem, nos poderemos } \\
\text { bem sobrepoiar com resguardamento das } \\
\text { perduravees cousas que ham de vĩir, sempre } \\
\text { ledos e nom movediços duraremos, nem de } \\
\text { casos que aconteçampresentes desprezados, } \\
\text { nem dos bẽes seremos levantados, ũu e o } \\
\text { outro, assi como cousa scorregavel e que } \\
\text { asinha passa, contemplando." }\end{array}$ \\
\hline
\end{tabular}

Rapidamente se constata que, a par da Collatio V, a espinha dorsal dos excertos do Leal Conselheiro é o livro IX das Inst. (De spiritu tristitiae), que obedece à estrutura: diagnóstico do estado de queda humanal / apresentação das vias medicinais de reparação (remedia quibus tristitiam de cordibus nostris exterminare possimus), critério também adoptado por D. Duarte sob a forma de conselhos ${ }^{121}$ e de bálsamos. Desespero, ira ou tristeza são palavras que o rei encontra em vários capítulos das obras de João Cassiano, contudo nem todo o campo lexical relativo aos sentimentos apresentado pelo Leal Conselheiro é devedor deste Padre da Igreja, porque o escrito português tem a marca da experiência vivencial do seu autor.

Sabemos que D. Duarte possuía umas Colações de letra pequena na sua livraria e que, segundo Toscano Rico, terá sido o "motivador da tradução"

120 João CASSIANO, Inst., cols. 359-360.

121 Daí que se possam reconstituir campo lexicais em torno da ideia de doença (1) e de cura (2). Damos apenas alguns exemplos, extraídos daquela que é em D. Duarte uma confluência de descrições psicossomáticas e físicas: "corpo destemperado", "destemperamento da compreissom", "doenças," "doença de humor menencorico," "doores," "mal da alma e do corpo", "enfermidade", "padecimentos", pestelencia, [vontade] tiba; (2) "curar", "curamento", "boa desposiçom corporal", "meezinhas", "purgar", "sangrias", "remedios" e "perservativos", "usança das pirolas comũus", "saude", "são". 
das Institutiones para língua portuguesa ${ }^{122}$. A estudiosa assevera ainda que esta segunda obra "mantém uma relação intertextual com o Leal Conselheiro que advém de uma situação de partilha: duas traduções de Cassiano, que se encontram no Leal Conselheiro atribuídas a D. Duarte foram compiladas no códice da tradução (Alc. 384), a par da tradução oficial..."123.

Já vários autores se debruçaram sobre as (débeis) capacidades de D. Duarte como tradutor, afastando a possibilidade de serem da sua autoria os excertos vertidos no $A B C$ da lealdade, à excepção da "oraçom de justo juiz Jesu Cristo." 124 Pese embora este facto, é notória a influência daqueles dois escritos do século V na arquitetura compositiva da obra portuguesa, quando analisada no seu todo orgânico e, em especial, no tratamento das paixões.

Mas, aparentemente nenhuma das paixões e nenhum dos pecados aí encontrados, ou escondidos nos fólios da biblioteca régia era de tão difícil correspondência noutra língua como esta suidade que D. Duarte decide trazer para o Leal Conselheiro e, em inadvertida oferta, legar como semente de uma "filosofia portuguesa".

\section{Suidade - a VI paixão}

Após uma exposição sobre a condição genérica do ser humano, ou melhor, do cristão, el-Rei mantém-se fiel ao propósito didactizante que o leva a escrever o tratado, elevando a sua circunstância pessoal a caso de estudo:

"Por quanto sei que muitos forom, som, e ao diante seram tocados deste pecado de tristeza que procede da vontade desconcertada, que ao presente chamam, e os mais dos casos, doença de humor menencorico, do qual dizem os fisicos que vem de muitas maneiras per fundamentos e sentidos desvairados, mais de tres anos continuados fui d'el muito sentido, e per special mercee de Nosso Senhor Deos houve perfeita saude. Com a teençom que primeiro screvi, de algũus desta breve e simprez leitura filharem proveitosa ensinança e avisamento, prepus de vos screver o começo, perseguimento e cura que d'el houve, por tal que minha speriencia a outros seja exempro ${ }^{125}$."

122 M. Toscano Rico, Recepção de João Cassiano e reflexos na formação da linguagem literária portuguesa (Dissertação de Doutoramento em Literatura Latina apresentada à Faculdade de Letras da Universidade de Lisboa, 2011, vol. 1), 91. Acrescente-se ainda a difusão em vernáculo de Cassiano na tradução parcelar das Inst. no alc. 212 e das Coll. no alc. 213.

123 Rico, Recepção, 91.

124 D. DuARte, Leal, LRI, 330: "E fiz logo screver a oraçom de justo juiz Jesu Cristo, que a vosso requerimento per mim traladei de latim em nossa linguagem assi rimada, na qual nom pude bem guardar que as palavras fossem scriptas, por as fazer consoar, nem se fez em melhor forma por levar a maneira em que per latim era feita."

125 D. DuARTE, Leal, XIX, 73. 
Está, portanto, subjacente à execução da obra a apresentação de um testemunho de vida dirigido ao indivíduo singular, numa clara complementaridade face à Vertuosa Benfeytoria de D. Pedro, voltada para o bem comum e para o corpo social. Ao ler os capítulos de índole autobiográfica do $L C$, verifica-se a necessidade sentida pelo filho mais velho de $\mathrm{D}$. João I de moldar o discurso à sua medida - ao seu tempo psicológico e ao seu espaço emocional. É de assinalar, aliás, a precisão temporal que pauta a narração das fases depressivas que o paciente atravessou: ${ }^{126}$ a referência aos três anos da crise emocional; a idade de 22 anos, altura em que os preparativos para a conquista de Ceuta e as responsabilidades governativas absorveram o ainda Infante D. Duarte e interferiram no seu estado de espírito, meditabundo, a ponto de se sentir já muito abalado na Páscoa; a percepção de que esta primeira crise durou dez meses; o aparente restabelecimento e a recidiva de seis meses; o anúncio da cura definitiva: "ao presente, graças a Deos, eu me tenho em geeral por mais ledo que era ante que da dicta infirmidade fosse sentido ${ }^{127}$." O rei coloca esta experiência - palavra que usa de forma não anódina - ao serviço dos outros, pelo conhecimento que julga ter da psicologia humana ${ }^{128}$, e pelo domínio da gramática de sentimentos benignos, lida pelo crivo cristão, e pelo conhecimento das tentações, até porque, mais do que na ciência médica ${ }^{129}$, confia no "corregimento" de hábitos e no cuidado com a alma, numa antevisão do reino dos céus.

Assim, chegado ao capítulo XXV, D. Duarte estabelece uma distinção entre nojo, pesar, desprazer, avorrecimento e suidade, alertando para certa imprecisão terminológica vigente ${ }^{130}$. Casos há em que o monarca propõe até um sinónimo mais conforme "à nossa linguagem", para palavras que resultam do decalque do latim ${ }^{131}$, e recorre à paráfrase - nomeadamente para cla-

126 D. DuARTE, Leal, XIX, 73-74.

127 D. Duarte, Leal, XIX, 77.

128 D. DuARte, Leal, XIX, 77 : "muitos adoecem de tristeza que sempre reina em seus corações, e por a nom poderem sofrer e desesperarem de saude, se matom ou se vão a perder onde nunca parecem.”

129 Convém não esquecer que integra o acervo de D. Duarte a obra Secretum Secretorum de Pseudo-Aristóteles, em linguagem, que contém várias indicações terapêuticas e mezinhas.

130 D. Duarte, Leal, XXV, 98: "E assi é bem visto como estas cousas som antre si apartadas, ainda que ũus nomes por outros se custumem chamar, mas aquelles que usarom de tal desvario de vocabulos, souberom que traziam, em realidade, verdadeira deferença."

131 D. DuArTe, Leal, III, 24: "E aqueste é o caminho da discliçom que, em nossa linguagem, chamamos verdadeiro siso, que per os sabedores é muito louvada...". E no cap. XVI, 62: "Da ira seu proprio nome em nossa linguagem é sanha, que vem de ũu arrevatado fervor de coraçom por desprazer que sente, com desejo de vingança." 
rificar o significado de acédia ${ }^{132}$ e de invídia, ${ }^{133}$ de prudência ou de avareza.

A suidade figurara já, de passagem, nos capítulos XVII, XVIII e XXIII, mas passa a ser alvo de atenção mais demorada apenas algumas páginas adiante. Em virtude de não aparecer descrita nos livros que consultara e de ter origens várias, ${ }^{134} \mathrm{o}$ monarca sugere que o leitor proceda a uma análise introspetiva para averiguar se terá vivido o sentimento saudoso em primeira pessoa, além de expor a sintomatologia que lhe está associada. São as linhas a seguir transcritas que hão-de compelir vários pensadores, pelos séculos fora, a insistir no carácter privativo da saudade portuguesa:

"E por em me parece este nome de suidade tam proprio que o latim, nem outra linguagem que eu saibha, nom é pera tal sentido semelhante. De se haver algũas vezes com prazer, e outras com nojo ou tristeza, esto se faz, segundo me parece, porquanto suidade propriamente é sentido que o coraçom filha por se achar partido da presença d'algũa pessoa, ou pessoas que muito per afeiçom ama ou o espera cedo de seer ${ }^{135}$."

Nesta breve descrição, a suidade aparece em relação com a dor da ausência e com a esperança do regresso da pessoa querida, que dulcifica o porvir. Este é um dos ramos da tristeza que o rei introduz por sua conta, sublinhando não conhecer equivalente na língua latina. Sabemos, porém, que a palavra encontrara no latim a sua seiva, mais concretamente no nome solitas, atis, na sua forma acusativa: $\operatorname{solitate}(m)^{136}$. Inicialmente associada, por isso, à solidão ${ }^{137}$, a saudade alimenta-se da memória quer nas suas colorações alegres,

132 D. DuARTe, Leal, LXVI, 256: “Aucidia é pecado per o qual o oucioso ha negligencia ou preguiça de demandar as virtudes e esquivar os pecados, e assi se doe do bem d'outrem, e se alegra do mal del."

133 D. Dunte, Leal, LXIIII, 254 : "Invidia é tristeza da bem-aventurança d'alguem, e de contrairo prazer, em livro Dicte. Invidia é tristeza que nom quer as bem-aventuranças d'outrem, segundo Hugo."

134 D. DuARTE, Leal, XXV, 98.

135 D. DuARTE, Leal, XXV, 98-99.

$136 \mathrm{Na}$ evolução do latim para o galego-português, o primeiro fenómeno fonético a registar-se é a apócope do -m final.

137 Carolina M. de VASCOncelos em A Saudade Portuguesa (Lisboa: Guimarães Editores, 1996), 53, mostra a evolução semântica da palavra: "Soedade designava um lugar ermo; o estado da pessoa que está só ou solitária sem companhia, quer no meio do mundo, quer apartada do mundo. Mas também significava isolamento em abstracto. (...) Do sentido isolamento derivaram muito cedo outros empregos abstractos: o de ausência, abandono, falta, míngua, carência, não só de pessoas, mas também de coisas necessárias ou desejadas, e o de desamparo, tristeza, melancolia." Não é difícil encontrar textos medievais em que soidade seja sinónimo de solidão e de ausência prolongada. 
quer nas evocações tristes ${ }^{138}$, num alinhamento temporal passado-presente que no século XX viria a ser projetado na eternidade ${ }^{139}$. Camões di-lo de forma magnífica num tempo áureo: Se só no ver puramente / me transformei no que vi / de vista tão excelente (...) Porque a alma namorada / a traz tão bem debuxada, / e a memória tanto voa / que se não a vejo em pessoa, / vejo-a n'alma pintada ${ }^{140}$."

Um simples odor, um som ou a lembrança de alguém, retida pelos olhos do coração, fazem recordar momentos remotos de felicidade (aqueles que instilam um estado saudoso) ou desejos incumpridos: eis a sensibilidade do nosso rei derramada na explicação do sentido de saudade. Ora, essa reminiscência suscita, por vezes, um condenável "desejo de tornar a tal estado e conversaçom"141, que faz resvalar o paciente para o abismo do pecado. Apesar de o sentimento saudoso não ser inspirado em Cassiano, a lógica de tratamento desta paixão é semelhante à que comparece nos vitia, julgados com desconfiança pela sua natureza perniciosa, mas também resgatados numa ou outra dimensão ${ }^{142}$.

Com efeito, quando a saudade passa a ser causa de uma "desordenança da voontade" e dá azo à sensação de morte tem de ser extirpada a todo o custo, porque os sentimentos mórbidos não glorificam o verdadeiro cristão. Se a auto-análise das paixões e a intervenção terapêutica podem ser redentoras, só em Cristo é possível descobrir o "nosso grande fisico e meestre"143, que tem unguentos para as chagas da alma e atenua a consciência da brevidade da vida ${ }^{144}$, lembrando aos detentores do poder temporal que os seus bens terrenos bem pouco significam aos olhos de Deus.

138 D. DuARTE, Leal, XXV, 99: “E quando nos vem algũa nembrança d'algũu tempo em que muito folgamos, nom geeral, mas que traga rijo sentido, e por conhecermos o estado em que somos seer tanto melhor, nom desejamos tornar a el por leixar o que possuimos, tal lembramento nos traz prazer.

139 António Quadros, A ideia de Portugal na literatura portuguesa dos últimos 100 anos (Lisboa: Fundação Lusíada, 1989), 98: “A saudade, palavra intraduzível, de origem galaico-portuguesa, como bem viu Pascoaes, é precisamente uma dessas palavras-mães a que se referia Goethe, um símbolo linguístico que abre imediatamente o pensamento a zonas que porventura esqueceria, não fosse a prospecção secular de todo um povo, através de muitos séculos, ter partido da vivência original da soledade ou da soidade, para chegar à vivência da saudade, que é aquela em que a solidão se descobre potencialmente transcendível pelo amor, ou, de outro ângulo, aquela em que o presente se descobre como eternidade, vinculado ao passado pela lembrança, vinculada ao futuro pelo desejo."

140 Luís de CAMÕES, "Se só no ver puramente", Rimas, texto estabelecido e prefaciado por Costa Pimpão (Coimbra: Almedina, 1994), 44.

141 D. DuARTE, Leal, XXV, 99.

142 João Cassiano, Coll., V, cap. XII - In quo sit utilis cenodoxia; Inst., IX, cap. X - In quo tantummodo sit nobis tristitia utilis.

143 D. DuARTE, Leal, XI, 46.

144 D. DuARTE, Leal, XI, 47 e XIX, 75. 
Mas, retomemos aqui a expressão acima utilizada - a anatomia da melancolia -, da autoria de Robert Burton $(1577-1640)^{145}$, para caracterizar, a partir de um mesmo nó agregador de sentido, estes capítulos do tratado quatrocentista português. Neste vasto tratado inglês, prenhe de sabedoria clássica, sinaliza-se a fonte da melancolia na queda adâmica, responsável pela miséria humana. São 88 os (de)graus da melancolia, minúcia analítica que ora a torna o centro, ora o pretexto para a escrita de um tratado médico em sentido mais lato. A solidão é a companheira predilecta do melancólico ${ }^{146}$, afiança o autor anglo-saxónico. Com efeito, Burton, ao abraçar simultaneamente as soluções da medicina e da teologia, aproxima-se um pouquinho do tom devocional do Leal Conselheiro e desenvolve uma dimensão que interessaria decerto a D. Duarte - a melancolia religiosa ${ }^{147}$ e um dos seus espinhos mais dolorosos, o desespero. Parece ser esta a última estação da via crucis percorrida por D. Duarte: vencidas as enfermidades psicossomáticas, interessa buscar a virtude e renunciar aos bens terrenos e à lei da aparência, ${ }^{148}$ num retorno da alma errante e apaixonada ao amor e temor a Deus.

O nosso rei consegue, assim, realizar no seu tratado de filosofia moral uma feliz união entre a medicina do corpo e da alma ${ }^{149}$, revitalizando princípios das correntes estóicas e epicuristas ${ }^{150}$.

145 Seguimos a ed. francesa : R. BurTon, Anatomie de la Mélancolie, ed. de Gisèle Venet (Paris: 2005).

146 R. Burton, Anatomie, 166-167 : «La solitude volontaire est souvent compagne de Mélancolie: telle une sirène, un aiguillon ou un sphinx, elle vous entraîne doucement vers ce gouffre sans retour. (...) Au commencement, il est fort agréable aux tempéraments mélancoliques de rester au lit des jours entiers et de garder la chambre, de se promener solitaires dans un bosquet désert entre un bois et une pièce d'eau ou au bord d'un ruisseau, ou encore de méditer (...).»

147 R. Burton, Anatomie, 336 : «il me faut nécessairement parler de l'objet de ce amour, Dieu lui-même, de ce qu'est cet amour, comment il séduit, d'où il procède, et (ce qui est la cause de toutes nos misères), comment nous nous laissons tromper, et nous en écartons pour errer loin de Lui.»

148 D. DuARTE, Leal, LXXXI, 297.

149 Vd. Adelino Cardoso "Filosofia e inteligibilidade médica", in: Arte Médica e Imagem do Corpo. De Hipócrates ao final do século XVIII, edit. por Adelino Cardoso et alii (Lisboa: Biblioteca Nacional, 2010).

${ }^{150}$ Cf. André-Jean Volke, La philosophie comme thérapie de l'âme (Paris : Éditions du Cerf, 1993). 


\section{Saudade: palavra intraduzível?}

É indiscutível o papel da Dinastia de Avis na valorização filosófica da nossa língua nos domínios da ética ${ }^{151}$, da moral e da política. D. Duarte teve desde cedo entrada na história da filosofia em Portugal ${ }^{152}$, mas terá sido a reflexão em torno da palavra suidade que granjeou maior notoriedade ao rei filósofo, sobretudo no que respeita ao involuntário impulso dado à filosofia da saudade ${ }^{153}$. Talvez tenha nascido no seio da literatura saudosista um equívoco pela tamanha insistência conferida ao problema da intraduzibilidade a partir da leitura de D. Duarte ${ }^{154}$. Na verdade, temos de admitir que a corte vivia entre duas línguas e que

“...D. Duarte, aliás, praticando a inclinação da época, escrevia numa língua que tanto devia à espontaneidade do português como ao classicismo do latim, em cujas regras lógicas vazava o pensamento, o que de certa forma, correspondia à união verbal entre «a geral maneira do nosso falar» e o escrever «na maneira do nosso viver» ${ }^{155}$."

A consciência desta realidade bilingue leva-nos, por isso, a acreditar que D. Duarte poderia estar familiarizado, através da poesia trovadoresca ${ }^{156}$, com o sentido da palavra suidade. Além disso, depois de ao longo do Leal Conselheiro ter clarificado o significado de uma série de latinismos, que chegavam à orla linguística portuguesa, era natural que registasse o movimento

151 Aires Nascimento, "Nova Idade, nova linguagem: entre afecto e alto desempenho de funções, a palavra no século XV", in: id. (ed.), Humanismo para o nosso tempo (Lisboa: Fund. Calouste Gulbenkian, 2004), 45: "De forma concreta, o homem do poder na corte de Avis exercita-se na sua língua materna para, através dela, tornar acessíveis os ensinamentos que mais interessa incutir nos súbditos. O poder tem missão cultural, é de intencionalidade ética, pela mediação da língua."

152 Referimos apenas as obras mais antigas em que surge citado: Lopes PraÇA, História da Filosofia em Portugal, 3. a ed. (Lisboa: Guimarães Editora, 1988), 90-94 (reed., Coimbra, 1868); J. de Carvalho, Desenvolvimento da Filosofia em Portugal, Coimbra: ,1927; Lothar Thomas, Contribuição para a História da Filosofia Portuguesa, trad. de António José Brandão (Lisboa: Clássica Editora, 1944), 117-132 e 142-149.

153 Recordamos com esta expressão a antologia Filosofia da saudade, selecção, organização de Afonso Botelho e António Braz Teixeira (Lisboa: IN-CM, 1986).

154 Este aspeto foi desenvolvido em Marisa das Neves Henriques, "Les intraduisibles: problème linguistique ou rhizome d'une pensée singulière?", Lire en plus d'une langue. Pour un espace poétique européen, dirig. par Isabelle Poulin, Bordeaux, Presse Universitaire de Bordeaux, 2013 (no prelo).

155 Afonso Botelho, introd. a D. Duarte (Lisboa: Verbo, 1991), 19.

156 É de notar que no seu acervo existia o Livro das Trovas del-Rey D. Deniz. Cf. Aires Nascimento, “As livrarias dos príncipes de Avis”, Biblos 69 (1993), 285. 
inverso, excepcional até. A saber: a comparência de uma palavra que designava um sentimento que, não sendo novo nem privativo, se dizia em língua portuguesa, sem que, aos seus olhos, tivesse um equivalente próximo noutra língua. Dessa feita, deixavam-se de lado (por serem desnecessárias) estratégias como a perífrase e o circunlóquio, e prescindia-se de citações de autoridade, em favor da experiência sentimental de cada um, já que a partilha dessa vergôntea da tristeza assinalada por D. Duarte se fazia com os seus leitores. Por conseguinte, não nos parece haver motivos para interpretar as palavras do filho mais velho de D. João I como a proclamação de uma sensibilidade exclusivamente portuguesa.

\section{Para uma definição de saudade}

Tentemos agora uma modesta e aproximativa definição de saudade, a partir do que nos é dito no capítulo XXV do $A B C$ da lealdade, avançando ainda algumas pistas para uma leitura diacrónica:

\begin{tabular}{|c|c|}
\hline \multicolumn{2}{|r|}{ Suidade: tentativa de reconstituição semântica } \\
\hline \multirow{6}{*}{ 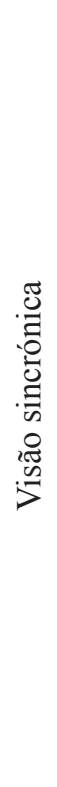 } & $\begin{array}{l}\text { classif. - uma das seis paixões, entre as quais se contam o ódio, a tristeza, } \\
\text { o nojo, o pesar e o desprazer. }\end{array}$ \\
\hline & $\begin{array}{l}\text { def. - "é ũu sentido do coraçom que vem da sensualidade, e nom da } \\
\text { razom, e faz sentir aas vezes os sentidos da tristeza e do nojo. E outros } \\
\text { vem daquelas cousas que a homem praz que sejam, e algũus com tal } \\
\text { lembrança que traz prazer e nom pena. E em casos certos se mestura com } \\
\text { tam gram nojo, que faz ficar em tristeza." }\end{array}$ \\
\hline & $\begin{array}{l}\text { Principais factores desencadeadores: i) a partida de alguém que o paciente } \\
\text { "muito per afeiçom ama, ou o espera cedo de seer", ausência que "faz } \\
\text { chorar e sospirar"; ii) falta sentida de "tempos e lugares em que per } \\
\text { deleitaçom muito folgou". }\end{array}$ \\
\hline & $\begin{array}{l}\text { Sentimentos contraditórios relacionados com a suidade: prazer, nojo, } \\
\text { tristeza, desejo. }\end{array}$ \\
\hline & Processo mental associado: memória. \\
\hline & $\begin{array}{l}\text { Remédios: resguardar-se de "tal paixom e sentimento"; ser virtuoso: orar } \\
\text { e arrepender-se. }\end{array}$ \\
\hline
\end{tabular}




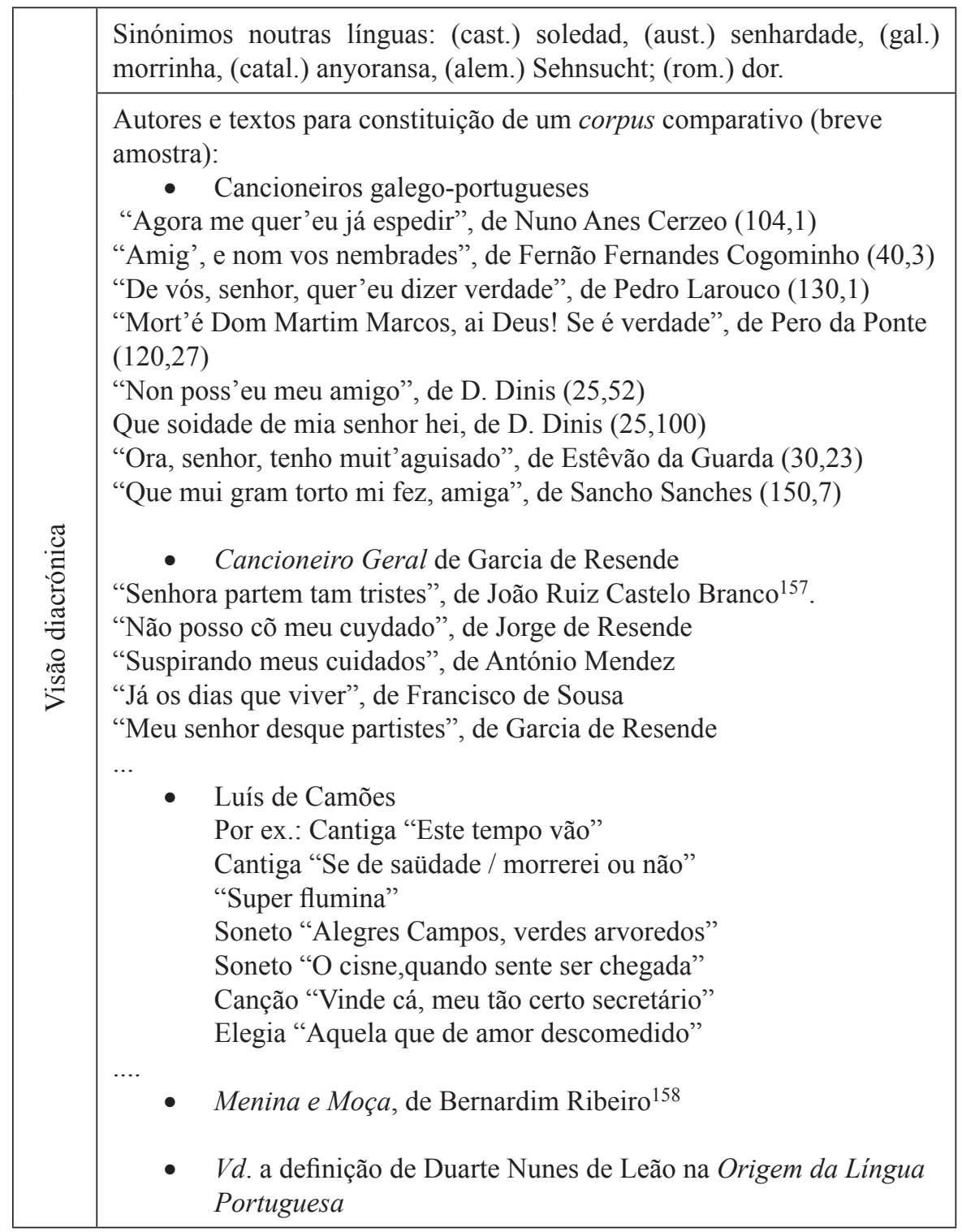

157 Pensamos especificamente no verso "Tão tristes, tão saudosos".

158 Bernardim Ribeiro, Menina e Moça ou Saudades, ed. de Juan Carrasco González (Coimbra: Angelus Novus, 2008). Vejam-se por exemplo as páginas 99, 105, 112, 116, 118, 136. 


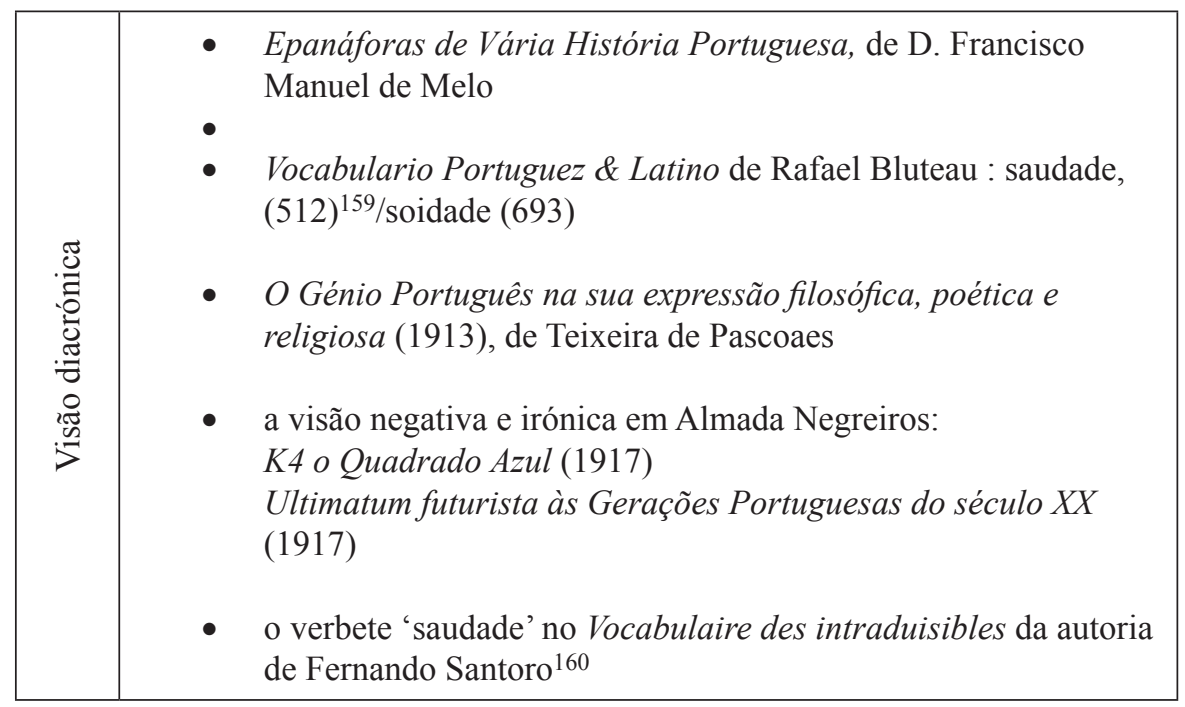

Voltemos ainda por instantes ao quadro (apenas à primeira parte) que sistematiza o que a suidade de D. Duarte, vivida nos anos 30 do século XV, nos transmite. Perturbação decorrente dos sentidos, com dimensões louváveis e outras menos positivas, ela inscreve-se no tipo de emoções que quebram e estiolam a vontade - outro lexema de grande valor filosófico no Leal Conselheiro $^{161}$ ( $v d$. Apêndice 2).

Analisada a definição quatrocentista de saudade, não parece legítimo concluir-se - baseando-nos nos elementos linguísticos que a estruturam e rejeitando qualquer critério extralinguístico - estarmos diante de um sentimento com assinatura galego-portuguesa nem portuguesa. A etimologia e o processo de cristalização semântica do lexema, que atravessou as veredas da

159 Transcrevemos apenas um pequeno excerto para aqueles que pretendam relembrar rapidamente esta entrada. Vd. Rafael Bluteau, Vocabulario Portuguez \& Latino (Coimbra: no Collegio das Artes da Companhia de Jesus, 1721, vol. 7), 512: "Na lingua Latina, para Saudade não temos palavra mais propria, que Desiderium, ii. Neut \& na minha opinião não deyxa de ser assaz expressiva, porque não ha saudade sem desejo, nem desejo sem pena em quãto se não logra o q se deseja." Não esqueçamos que também D. Duarte no Leal Conselheiro, cap. XVIII, 70, explica que uma das "duas maneiras de tristeza" nasce de um "desejo que nom [se] comprio."

160 Vocabulaire Européen des philosophies. Dictionnaire des intraduisibles edit. par Barbara CAssin (Paris: Seuil-Le Robert, 2004), 1115-1117.

161 Pela importância analítica que o rei lhe confere, esquissamos em anexo uma sistematização dos traços semântico de vontade, que pode vir a ser enriquecida com uma leitura transversal de todas as obras produzidas pela Dinastia de Avis. 
solidão e, segundo nos ensina Carolina Michaëlis, talvez as de saúde e de salvação ${ }^{162}$, bem como a falta de um sinónimo perfeito noutra língua, terão oferecido aos saudosistas um pretexto para afinarem a relação entre as singularidades da língua e a sensibilidade do povo luso. Porém, é sabido que, em bom rigor, a sinonímia é sempre parcial, e que a tradução (para mais ad verbum) resulta sempre de um pacto mediador entre a língua de partida e a língua de destino.

Assim, pela consulta do Vocabulaire européen des philosophies constata-se o quão traiçoeira se revela a aspiração à existência de uma espécie de $m o t$ juste, sem correspondência em mais nenhuma língua europeia, relativamente a um dado estado de espírito ou atitude pensante. Da mesma forma, talvez seja demasiado fatalista pensar na insularidade do pensamento por carência de um sinónimo perfeito.

Socorremo-nos de dois exemplos apenas, um deles para retomar a acedia que encontrámos tanto nas Inst. de Cassiano como em D. Duarte. Na obra editada por Barbara Cassin, a ACEDIA aparece na secção dedicada aos intraduzíveis castelhanos, mas parece haver, desde logo, duas objecções a fazer ao autor do verbete: 1) se a palavra é um decalque do latim monástico ${ }^{163}$, não poderão pelo menos as línguas românicas usar o latinismo, sem prejuízo do conteúdo a veicular? 2) Nas remissões entre palavras, o leitor que consulta este verbete é convidado a ler umas tantas entradas, em várias línguas: "malaise [mélancolie, spleen], et dasein, desengano, oikeiôsis, sorge, vergüenza"164. Não estará, então, dada uma solução provisória à dificuldade de traduzir a palavra, através deste diálogo sinonímico ou intenta perpetuar-se a diafaneidade e o mistério pelo nome unívoco a atribuir-lhe?

Miguel Marinas sublinha que a acédia consubstancia duas vertentes semânticas muito ricas - uma psicológica, outra teológica -, cujo uso mostra ser volúvel ao longo dos tempos, tendendo a circunscrever-se. Mas, os fenómenos de redução semântica fazem parte da história evolutiva das palavras, determinada pela acção da comunidade de falantes. Bem diferente será a noção de que se perdem traços de significado pela escolha de uma outra palavra existente na língua de chegada, procedimento que não se traduz forçosamente numa perda substancial de sentido em algumas das palavras que integram este Vocabulaire.

162 Carolina M. de Vasconcelos, A Saudade Portuguesa, 50.

163 Consulte-se Pierre Miquel, Lexique du désert. Étude de quelques mots-clés du vocabulaire monastique grec ancien (Bégrolles-en-Mauges : Édition abbaye de Bellefontaine, 1986), 19-35.

164 José Miguel Marinas, “Acedia”, in Vocabulaire, 8. 
Um segundo exemplo: MÉLANCOLIE ${ }^{165}$, sentimento que D. Duarte inclui na sua descrição do "humor menencorico", e que relembra a teoria hipocrática e os ensinamentos de Galeno. A autora do verbete opta por um tratamento histórico-literário da melancolia, o que instiga a deixar a seguinte pergunta em aberto: será que a palavra-ideia assim reconstruída não representa antes um legado da cultura ocidental e não tanto um intraduzível da língua francesa? Para mais, o reconhecimento da oscilação semântica da palavra, consoante a aproximação clínica escolhida pelas várias correntes da psiquiatria alemãs e francesas, não parece insolúvel, porque é o contexto em que a palavra se insere que é passível de ser alterado. A palavra permanece lá, sujeita, isso sim, a reconfigurações e a processos de redução e de extensão semântica.

Pelo contrário, e a favor da sua riqueza semântica e da vitalidade linguística ${ }^{166}$, o uso da palavra melancolia, ciente das suas aportações filosóficas e médicas ${ }^{167}$, dos contributos anglo-saxónicos e germânicos, é revelador de abertura e plurissignificância, mais rentável que qualquer fechamento proporcionado por uma gíria profissional.

De facto, preferimos a atitude optimista de José Gil que encara com naturalidade a existência de "estilos" nas linguagens científicas e filosóficas, pois "os particularismos desdobram-se em oportunidade e restrições, como uma maior ou menor inventividade morfológica ou sintáctica, ou um maior ou menor controlo da ambiguidade ${ }^{168}$."

165 Marie-Claude Lambotte, «Mélancolie» in : Vocabulaire, 758-765. Neste caso, as remissões para outras palavras ainda são mais abundantes : "acedia, desengaño, dor, es, feeling, folie, Gemüt, génie, ingenium, je, leib, malaise, pathos, saudade, Sehnsucht, spleen, Stimmung. "

166 Há neste esforço taxinómico da ciência relativamente à melancolia curiosas ressonâncias daquilo que encontramos no Leal Conselheiro ou na obra de Burton. Atente-se num excerto de Marie-Claude LAmвотте, «Mélancolie», Vocabulaire, 761-762: «La richesse de ce vocabulaire, outre son application à la mélancolie qui fait de cette dernière non pas tant une entité morbide qu'une disposition, ou bien encore un typus (...) En ce qui concerne précisément la mélancolie, la classification allemande distinguait une mélancolie simple (melancholia simplex) et une mélancolie avec stupeur (melancolia errabunda, melancolia agitans sine activa), et, relativement à ces deux formes, une mélancolie précordiale, une mélancolie délirante, encore appelée religieuse, et une mélancolie hallucinatoire...».

167 Marie-Claude Lambotte, «Mélancolie», Vocabulaire, 761.

168 José GiL, “Como pensa a língua”, Análise 12 (1989), 186. 


\section{Uma língua apenas apta para (não) dizer saudade?}

Uma vez que, depois da morte de D. Duarte, só temos notícia do Leal Conselheiro no século XIX, por acção do Abade Correia da Serra e pelas edições de 1842 e de 1843, é natural que, no período de Seiscentos, D. Francisco Manuel de Melo confesse o entusiasmo de reflectir inauguralmente sobre a palavra saudade:

"E pois parece, que lhes toca mais aos Portuguezes, que a outra nação do mundo, o darlhe cõta desta generosa paixão, a quem sómente nòs sabemos o nome, chamãdolhe: Saudade; quero eu agora tomar sobre mi esta noticia. Florece entre os Portuguezes a saudade, por duas causas, mais certas em nòs, q em [D290] outra gente do mundo; porque de ambas essas causas, tem seu principio. Amor, e Ausencia, são os pays da saudade; e como nosso natural, he entre as mais nações, conhecido por amoroso, e nossas dilatadas viagẽs, ocasionão as mayores ausencias, de ahi vem, que donde se acha muyto amor, e ausencia larga, as saudades sejão mais certas, e esta foi sem falta a razão, porque entre nós habitassem, como em seu natural centro. Mas porque tenho por certo, que fui eu o primeiro neste reparo, parece que não serà reprehensivel, que me detenha algum tãto, por fazer anotomía em hum afecto; o qual ainda que padecido de todos, não temos todavia averiguado, se compete às injurias, ou aos beneficios, que do amor recebem os humanos: ou se sem amor, tãbem, se podem experimentar saudades. (...) He a Saudade, hũa mimosa paixão da alma, e por [D291] isso tão sutil, que equivocamente se experimenta, deixãdonos indistinta a dor, da satisfação. He hum mal, de que se gosta, e hum bem, que se padece; quando fenece, trocasse a outro mayor contentamẽto, mas não que formalmente se extinga: porque se sem melhoria se acaba a saudade, he certo, que o amor, e o desejo, se acabarão primeiro; $(\ldots)^{169} . "$

Sem conhecer o texto medieval, o autor seiscentista também coloca a tónica na singularidade do saudoso sentir português e reitera a importância do amor e do ónus doloroso da ausência no agudizar desse sofrimento "nacional". Paixão da alma antinómica (já o havíamos lido antes), a saudade surge de mãos dadas com o desejo, numa alegria intermitente, num pesar a que inevitavelmente se regressa para bem do paciente ou do amante ${ }^{170}$.

169 D. Francisco Manuel de Melo, Epanáforas de vária história portuguesa, ed. semidiplomática de Evelina Verdelho (Coimbra: CELGA, 2007), 184-185.

170 Como é sabido, semelhante forma de expressão paradoxal assumira em Camões não a saudade, mas o amor: "é um contentamento descontente, / é dor que desatina sem doer (...) é um andar solitário entre a gente / é nunca contentar-se de contente; / é um cuidar que ganha em se perder." 
Em 1606, Duarte Nunes de Leão incluía a suidade entre as "palavras portuguesas e maneiras de falar que se não podem bem explicar por outras latinas nem de outra língua" "171, sem se desviar muito da observação feita pelo autor do Leal Conselheiro, mas incorria no vício de indagar nas características psicológicas dos portugueses uma razão de ser para a sedutora sobrevivência da palavra. Nem o facto de se inscrever no grupo de estudiosos da língua portuguesa ${ }^{172}$ da época o poupou dessa incursão pela crítica impressionista e emotiva.

Ora, os herdeiros simbólicos e tardios (da saudade literária) de D. Duarte eram apenas os discípulos do saudosismo que já conheciam o seu tratado e o citavam por enviesada conveniência. No fundo, a problemática não era muito abonatória para a filosofia em língua portuguesa, porque Pascoaes insistia que entre nós "a emoção poética antecede o pensamento filosofico. Primeiro, formou-se a névoa e o relampago e depois e condensação em forma logica e dialectica ${ }^{173}$." Os portugueses seriam, então, a julgar pelos escritos de Pascoaes, e de alguns dos seus condiscípulos, capazes de sentir como ninguém a saudade, mas, por excesso de génio emotivo, incapazes de pensar filosoficamente sobre ela... ${ }^{174}$. Daí que pareça estabelecer-se um paradoxo na construção de uma filosofia portuguesa assente em determinadas palavras, quando se antepõe a pura emoção à reflexão meditativa e se rasura o pensamento em nome do sentir.

Por seu turno, era de grande inquietação a pergunta formulada por António Quadros sobre as verdadeiras apetências da nossa língua e sobre a sua

171 Duarte Nunes de LẼ̃o, Ortografia e Origem da Língua Portuguesa (Lisboa: IN-CM, 1986), 304: "Saudade - este aspecto como é próprio dos Portugueses, que naturalmente são maviosos e afeiçoados, não há língua em que da mesma maneira se possa explicar, nem ainda por muitas palavras que declare bem. Porque, por que os Latinos chamam desiderium, não é isso propriamente (...) Pelo que, parece que mais lhe podia quadrar e esta definição que é: lembrança de algũa cousa com desejo dela".

172 Sobre este assunto, $v d$. Rosa Mattos e Silva, Alguma reflexão sobre "A origem da língua portuguesa" de Duarte Nunes Leão", disponível em linha. Consulte-se para o séc. XVI o artigo de Ponce de León Romeo, "Gramaticografia e lexicografia em Portugal durante o século XVI: do latim ao português", Limite: Revista de Estudios Portugueses y de la Lusofonía 3 (2009), 45-65.

173 Teixeira de Pascones, O Génio Português na sua expressão filosófica, poética e religiosa (Porto: Renascença Portuguesa, 1913), 22. Mantivemos a grafia original.

174 Teixeira Pascoaes, Arte de Ser Português (Lisboa: Assírio \& Alvim, 1998), 77: “A emoção afoga a inteligência, ultrapassando-a como força criadora. E assim, corresponde à nossa superioridade poética, uma grande inferioridade filosófica. (...) O português não quer interpretar o mundo nem a vida, contenta-se em vivê-la exteriormente; e tem, por isso, um verdadeiro horror à Filosofia, imaginando encontrá-la em tudo o que não entende." 
capacidade de resistência face a outros idiomas e a outras linguagens ${ }^{175}$. Não era tanto o complexo de inferioridade pelo estatuto ancilar da língua portuguesa para a formação de um pensamento europeu mais universalista, mas, pelo contrário, o temor pela perda da sua identidade que saudade e outras palavras de "origem épico-marítima" preservavam ${ }^{176}$.

Em contracorrente, na polémica travada com Pascoaes, António Sérgio diz que a saudade é traduzível ${ }^{177}$ e responde com exemplos linguísticos concretos. Já Barata-Moura ${ }^{178}$, na sua desconstrução do mitema saudosista, salientará o autocomprazimento na dor que o sentimento-ideia hasteado pelo mentor de A Águia nutre, numa mescla de emoções indefinidas. Noutras eras e por outras paragens, Victor Hugo virá a dizer que "La mélancolie, c'est le bonheur d'être triste ${ }^{179} . »$

Ganhará, então, a palma a língua poética, por dizer emocionalmente a saudade, em detrimento da filosofia que a pensa e relativiza a sua singularidade?

175 António Quadros, O Espirito da Cultura Portuguesa (Lisboa: Sociedade de Expansão Cultural, 1967), 41: "Devemos abandoná-la [a língua portuguesa] como instrumento gnoseológico e intelectual, cedendo à invasão dos estrangeirismos, à ilusão do esperanto, às incursões da linguagem matemática para fora do seu domínio quantitativo - ou pelo contrário devemos desenvolver e vitalizar a sua específica potencialidade criadora, considerando-a alicerce essencial da nossa filosofia e de um modo geral da nossa cultura?"

176 António QuAdros em O Espírito, 76, elege dez "palavras que nos soam tão familiares aos ouvidos, que nem reparamos na originalidade das meditações que nos sugerem: Mar, Nau, Viagem, Descobrimento, Demanda, Oriente, Amor, Império, Saudade, Encoberto."

177 António SÉrgio, "Epístola aos saudosistas" apud Teixeira de PASCOAes, A saudade e o saudosismo (dispersos e opúsculos), compilação, introdução e notas de Pinharanda Gomes (Lisboa: Assírio \& Alvim, 1988), 101: “Com efeito, muito ao contrário do que Pascoaes afirma, a palavra saudade é traduzível. Várias nações a representam por um termo especial: o galego tem soledades, soedades, saudades; o catalão, anyoransa, anyoramento; o italiano, desio, disio; o romeno, doru, ou dor; o sueco, saknad; o dinamarquês, savn, e o islandês, saknaor...".

178 J. Barata-Moura, "Peso, pêsame, pesadelo - para um sopesamento (não saudosista) da saudade", Estudos de Filosofia Portuguesa (Lisboa: Caminho, 1998), 200: "Muito pelo contrário, o desprendimento da objectualidade no decorrer de experiências de saudade costuma inflectir numa outra direcção, igualmente possível: a da fruição objectivamente indeterminada do próprio sentimento, a deleitação estésica na clausura, a autofagia sentimental comprazida."

179 Victor Hugo, Les Travailleurs de la mer (Paris: Librairie Internationale, 1866), III, 154. 


\title{
Da sombra melancólica à vontade ordenada.
}

\author{
O humor é uma desilusão alegre. Nisto ele é, ou pode ser, duplamente \\ virtuoso: como desilusão raia a lucidez (e, portanto, a boa fé); como alegria, \\ raia o amor, raia tudo. \\ André Comte-Sponville
}

Enquanto não criamos uma antologia de textos portugueses sobre a melancolia ${ }^{180}$ e não aprofundamos o conhecimento da filosofia em língua portuguesa no século $\mathrm{XV}$, talvez fosse possível criar umas quantas entradas de dicionário como a que esboçámos para suidade a partir de vocábulos existentes no Leal Conselheiro, obra em que o rei se esforça por "screver na geeral maneira de nosso falar" 181 e onde maneja vocabulário filosófico-teológico ainda pouco habitual na nossa prosa medieval de teor filosofante. Nem Jesuína Pereira ${ }^{182}$, nem Alice Almeida ${ }^{183}$ vão além da reunião de um conjunto de palavras extraídas do livro de D. Duarte, mas de desigual valor ${ }^{184}$, com o objectivo futuro e incumprido de as integrar num dicionário do português arcaico. Semelhante malogro se diagnostica em dois trabalhos produzidos além-fronteiras no ano de $1940^{185}$. Coube a Herbert Palhano dar um passo em frente para a organização do léxico filosófico de D. Duarte ${ }^{186}$, mas o seu esforço meritório não teve continuadores. Mesmo alguns trabalhos acadé-

180 Pela análise do volume de Yves Hersant (ed.), Mélancolies (Paris: Robert Lafont, 2005), e em particular do brevíssimo subcapítulo "Mélancolies médievales", que foca a melancolia e a acédia, constatamos que seria perfeito legítimo incluir o relato autobiográfico de D. Duarte num volume antológico sobre esta temática.

181 D. DuARTE, Leal, dedicatória, 11.

182 Jesuína Inês Pereira, Glossário do Leal Conselheiro até ao capitulo XXV (inclusive) (Tese de licenciatura em Filologia Românica, apresentada à Faculdade de Letras de Lisboa, 1943).

183 Maria Alice da Silva Almeida, Contribuições para o Dicionário Arcaico Português (Um glossário do Leal Conselheiro) (Tese de licenciatura em Filologia Românica apresentada à Faculdade de Letras da Universidade de Lisboa, 1947).

184 De desigual valor na medida em que tanto reúnem palavras com valor funcional, como importantes lexemas filosóficos: alma, amar, alvydro, amor, arte, consciência, conhecimento, conhecer, contemplaçom, etc.

185 Kimberley RoBerTs, Orthography, phonology and word study of the leal conselheiro (Dissertação de Doutoramento em Filosofia apresentada à Universidade da Pensilvânia, 1940); Harold Russo, Morphology and Syntax of the Leal Conselheiro, (Dissertação de Doutoramento apresentada à Universidade da Pensilvânia, 1940). Ambas as dissertações são extremamente superficiais, optando os autores por uma abordagem esquemática, ao invés de enveredarem por um tratamento semântico ou lexicográfico do vocabulário.

186 Herbert Palhano, A Expressão léxico-gramatical do 'Leal Conselheiro' (Lisboa: Revista de Portugal, 1949). 
micos que se fixam em vocábulos usados com particular força ilocutória por D. Duarte enfermam de uma deriva ${ }^{187}$ e de um espírito perfunctório.

É por ainda acreditarmos na consecução e pertinência dessa tarefa que deixamos em apêndice uma pequena lista de palavras com interesse filosófico ( $v d$. apêndice 3$)$, bem como algumas pistas de trabalho com o intuito de, a partir de informações existentes no interior do Leal Conselheiro, se proceder à reconstituição da sua semântica. Quem sabe se por esta via será possível dar expressão concreta às valiosas reflexões de Gama Caeiro ${ }^{188}$.

Seleccionámos apenas vocábulos cujo significado é apresentado ao longo do tratado. Daí que não se tenham contemplado palavras cujo alcance semântico se infere da leitura interpretativa do escrito filosófico de el-Rei (alma, corpo, culpa, intenção, sentidos, tempo...), mas de que não há rasto de definição nem de tentativa parafrástica pelo punho de $\mathrm{D}$. Duarte.

O contexto em que cada uma das palavras surge é muito diverso, uma vez que o rei nem sempre define os filosofemas. Em casos como o de fantesia, não vai muito além da mera tentativa de transposição da palavra latina para o português, procedimento que nos chega na primeira pessoa: "nom escrevo esto per maneira escolastica, mas o que leeo per livros de latim e de toda lingua ladinha, do que algũa parte se me entende, concordo com a pratica cortesãa" na mais conveniente maneira que me parece"189.

Os dados colocados ao dispor do leitor são apenas o início de um caminho a aperfeiçoar ou até a reconstruir. Se a saudade pode enfraquecer a intrepidez da vontade, segundo D. Duarte, em pleno século XXI, reunamos vontades, com o mesmo denodo com que Blimunda o fazia pela cidade de Lisboa assolada pela peste, para que o homem voasse, e criemos um léxico filosófico do português medieval, para enriquecermos o capítulo da história da Filosofia em Portugal e nos afastarmos da sombra melancólica que paira sobre a nossa Idade média pensante.

187 Acir F. MeIrelles, Consciência e Vontade no Leal Conselheiro (Dissertação de Mestrado em Cultura Portuguesa apresentada à Universidade dos Açores, 1997); Maria Dalila D. de Oliveira, D. Duarte, educador: uma abordagem interdisciplinar das relações da vontade com a razão no Livro da Ensinança de Bem Cavalgar Toda Sela (Dissertação de Mestrado em Filosofia apresentada à Universidade do Minho, 1998).

188 Gama CAeIro, "Dom Duarte à luz da cultura portuguesa", Revista Portuguesa de Filosofia 47 (1991), 407-438. A págs. 410, o professor faz notar que D. Duarte está "próximo do nosso tempo" "pela atitude teórica que parece prenunciar a preocupação cartesiana das ideias claras, simples e distintas". E acrescenta ainda: "Os vocábulos recém-introduzidos, vistos assim em seu conjunto, oferecem uma nota insuspeitada de inegável interesse históricofilosófico: a procura de modos expressivos de âmbito teorético, o predomínio de conceitos de relação e de referência abstracta, o esforço de dilucidação terminológica no domínio da filosofia e da moral".

189 D. DuARTe, Leal, XXVII, 111. 


\section{APÊNDICE 1}

Autores e títulos citados ${ }^{190}$ no Livro da Vertuosa Benfeytoria - subsídios para a história da recepção da literatura filosófica clássica e medieval europeia em autores portugueses

ARISTÓTELES

- Alma [De Anima]

- Apanhamento natural

- Celi et mundi [De caelo et mundo]

- Ensinança politica

- Fisicos [Physica]

- Livros naturaaes [Parva naturalia]

- livro postumeyro da Logica [Logica nova]

- Moral philosophia

- Natural phylosophya

- Predicamentos [Categoriae?]

- Policia [Politica]

- Retorica [Ars rhetorica]

- Transcendente philosophia/Methafisica [Metaphysica]

Marco Túlio CíCERo*

- Officios [De officiis]

- Rectorica [De inventione]

SÉNECA *

- Epistulae morales ad Lucilium ${ }^{191}$

- De clemencia

- De tranquilitate animi

- Declamaçõoes [obra apócrifa: Controversiae et Suasoriae]

- Livro dos costumes [obra apócrifa: De moribus]

190 Transcrevem-se os títulos tal como surgem ao longo da Virtuosa Benfeytoria. Não se quer, no entanto, afirmar com a ordenação desta listagem que os títulos referidos foram consultados em primeira mão, até porque circulavam antologias e catenae com ditos dos Padres da Igreja e da sabedoria antiga.

Quando surgem deturpados ou parcialmente omissos, inserimos a informação entre [ ]. Assinala-se com ${ }^{*}$ os autores e / ou títulos que surgem mencionados no rol de livros de D. Duarte.

191 A inclusão desta obra aqui prende-se com o facto de termos identificado uma passagem do texto da Vertuosa Benfeytoria, genericamente atribuída a Séneca, com um passo específico das Epistulae. Para uma leitura comparativa, vd. SÉneCA, Cartas a Lucílio, trad. de Segurado e Campos, 4. ${ }^{\text {a }}$ ed. (Lisboa: Fund. Calouste Gulbenkian, 2009), Livro XVI, carta 99, 539 e Livro da Vertuosa Benfeytoria, II, XXV, 147, linhas 13-15. 
- Livros dos benefficios [De beneficiis]

- Proverbios [obra apócrifa: Proverbia or Sententiae]

VALÉRIO MÁXIMO*

- Feytos nembradoyros [Factorvm et dictorvm memorabilivm libri novem]

OvíDIo

- Livro do Ponto [Epistulae ex Ponto]

PORFÍRIO

- Lógica [Isagoge]

Eusébio de CesAREIA

- Storia ecclesiastica

MACRÓBIO

- [Commentarii in Somnium Scipionis $]^{192}$

ST. Ambrósio

- Evangelho de S. Mateus [De Concordia Matthaei Et Lucae In Genealogia Christi]

- Hexameron [Hexameron Libri Sex]

St. Agostinho*

- A cidade de Deus [De civitate Dei]

- Confissões * [Confessionum]

- Triindade [De trinitate]

- Livro das obras dos monges [De Opere Monachorum liber unus]

- Livro dos custumes ecclesiasticos [De Moribus Ecclesiae et de Moribus Manichaeorum libri duo]

- Ensinança dos christaãos [De doctrina christiana]

Pseudo-Dionísio Areopagita

- Livros dos nomes de Deus [De divinis nominibus]

BoÉCIO

- Consolaçom [De consolatione philosophiae]

- Livro da ensinança dos scollares [obra apócrifa: De disciplina scholarium]

S. JoÃo CLímaCo

- Livro de Climaco ${ }^{193}$ [Scala Paradisi]

192 Pontes, "Cícero", col. 395, crê que esta alusão é feita via Cícero. 
SÃo GrEGórIO

- Diálogos

- Moral [Moralia in Job]

St. Anselmo

- Livro da predistinaçom e da graça [De Concordia Praescientiae Et Praedestinationis Et Gratiae]

- Livro do concebimento original [De conceptu virginali et de peccatu originali]

Hugo DE S. VICTOR

- Didascalicom

- Livro da ensinança meestral [reporta-se também ao Didascalion]

Jõ̃o DE SALISBúRIA

- Policraticus

Alberto Magno

- Celestial hierarchia [Commentarium in Dionysium Aeropagitam De caelesti hierarchia?]

JoHAM DE GALEZ

- Livro do comũu falamento das cousas que a todollos stados perteecem [Summa de regimine vitae humanae seu margarita doctorum?] de Johannes Guallensis

S. TomÁs DE Aquino

- Soma de theolisia [Summa theologiae]

- Livro da ensinança dos princepes [De regimine principum]

- [comentário] às Sentenças

- De potentia Dei

EGÍDIO ROMANO

- Livro do regimento dos principes*

Gualter Burley

- Livro da vida e costumes dos philosophos [De vitae et moribus philosophorum]

\section{Guido de Coluna}

- Livro da Troya ${ }^{194}$ [Historia destructionis Troiae de Guido de Columna]

193 Existente na lista de livros pertencente ao Infante Santo com uma descrição similar à que surge na Vertuosa Benfeytoria: "Huum liuro que chamam Crimaco".

$194 \mathrm{Na}$ lista de obras pertencentes a D. Duarte, surge um título com a seguinte informação: Historya de Troya, per aragoes. Também numa das glosas das Coplas do Condestável D. Pedro, num passo onde se fala dos filhos do rei Príamo, remete-se para informação fornecida por "Guido de Colupnis" (sic!) (67). 


\section{APÊNDICE 2}

O lexema vontade no Leal Conselheiro

\begin{tabular}{|c|c|}
\hline \multicolumn{2}{|r|}{ VONTADE } \\
\hline \multirow{3}{*}{ 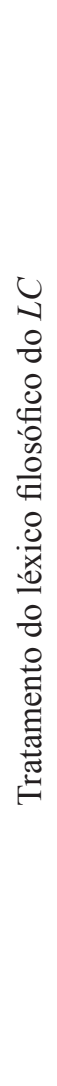 } & $\begin{array}{l}\text { classificação - No } L C \text {, distinguem-se quatro tipos de vontade: 1) carnal; } \\
\text { 2) espiritual; 3) "tiba prazenteira"; } 4 \text { ) perfeita e virtuosa. As três primeiras } \\
\text { são "desordenadas", por isso há bons motivos para lutar contra elas } \\
\text { (cap. V). Cada tipo de vontade tem inclinações diferentes, mas apenas a } \\
\text { "vontade virtuosa" é aconselhável e conduz o homem ao bom caminho, } \\
\text { além de ser a única determinada pela razão e pelo entender. } \\
\text { São vários os perigos a que "a tiba vontade" expõe pessoas de todas as } \\
\text { extracções sociais e mesteres (cap. IV). } \\
\text { Para cada perfil de homem existe também um tipo de vontade (cap. VIII): } \\
\text { 1) pequeno entender e saber: vontade revesada, } \\
\text { 2) grande entender e saber: vontade maliciosa; } \\
\text { 3) curto entender e saber, mas vontade justa e dereita; } \\
\text { 4) mui grande e sotil entender: vontade bem chãa, justa e firme }\end{array}$ \\
\hline & $\begin{array}{l}\text { definição - a vontade pode brotar do coração ou da razão e pressupõe que } \\
\text { todas as acções humanas se realizem por "scolhimento" e "deliberaçom". } \\
\text { A vontade desconcertada, ou seja, aquela que a razão abandona, provoca } \\
\text { tristeza e pode ser a principal fonte de "humor menencorico." (cap. XIX). } \\
\text { A par da memória, a vontade é requisito essencial do bom entendimento; } \\
\text { alcançar a perfeição é o seu principal fito (cap. XXIV). Um acto de } \\
\text { vontade pode determinar a existência ou não de culpa (cap. XXVII).Em } \\
\text { diálogo com a palavra "obrigaçom" (cap. XXIX), a vontade surge como } \\
\text { seu antónimo. A confiança também é do domínio da vontade. }\end{array}$ \\
\hline & $\begin{array}{l}\text { Rede de conceitos associados: entendimento, livre-arbítrio, memória, } \\
\text { pensamento, razão. }\end{array}$ \\
\hline
\end{tabular}




\section{APÊNDICE 3}

Leal Conselheiro de D. Duarte - levantamento de algum do seu vocabulário filosófico

\begin{tabular}{|c|c|c|}
\hline Vocábulo & Significado na obra & Existência de definição \\
\hline Conhecimento & $\begin{array}{l}\text { forma ponderada de agir; } \\
\text { sinónimo de consciência / auto- } \\
\text {-conhecimento; } \\
\text { entendimento (cap. XLIV) }\end{array}$ & $\mathbf{x}$ \\
\hline Entender & $\begin{array}{l}\text { repartido em: entender agente, } \\
\text { possível, especulativo e prático. }\end{array}$ & $\mathbf{x}$ \\
\hline Entendimento & $\begin{array}{l}\text { sinónimo de inteligência, de } \\
\text { usoda razão, divide-se em } 6 \\
\text { partes: aprendizagem; memória; } \\
\text { [faculdade] "judicativa", } \\
\text { [capacidade] inventiva; } \\
\text { capacidade comunicativa; } \\
\text { capacidade "executiva". }\end{array}$ & \begin{tabular}{l}
\multicolumn{1}{c}{$\mathbf{x}$} \\
considerada a principal \\
virtude $(v d$. ded.)
\end{tabular} \\
\hline Fantesia & $\begin{array}{l}\text { sinónimo de scurrilitas } 195 \\
\text { (“soltamento de fantesia”), } \\
\text { desenha-se já a nuance de } \\
\text { ilusão, imaginação (cap. } \\
\text { XXXIX) }\end{array}$ & $\mathbf{x}$ \\
\hline Livre alvidro & sinónimo de vontade & $\begin{array}{c}\checkmark \\
\text { (caps. VI, XXXIX) }\end{array}$ \\
\hline Memória & $\begin{array}{l}\text { duas dimensões: racional e } \\
\text { sensual. } \\
\text { a escrita: melhor exercício de } \\
\text { "arte memorativa". }\end{array}$ & $\mathbf{x}$ \\
\hline Paixão & $\begin{array}{l}\text { afecção da alma, } \\
\text { pertence à vontade sensitiva } 196\end{array}$ & $x$ \\
\hline
\end{tabular}

195 Fantesia surge também com esta acepção de chocarrice em Gil Vicente, no Auto da Barca do Inferno (1562). Vd. a fala do anjo dirigindo-se ao fidalgo: “- Pera vossa fantesia / mui pequena é esta barca."

196 D. DuARTE no Leal, VI, 32, enumera doze paixões: "d'amor, desejo e deleitaçom; odio, avorrecimento e tristeza; mansidõe, sperança e atrevimento; sanha, desesperaçom e medo." 


\begin{tabular}{|l|l|c|}
\hline Prudência & $\begin{array}{l}\text { virtude cardeal, e de natureza } \\
\text { intelectual }\end{array}$ & $\begin{array}{c}\checkmark \\
\text { (cap. LIX) }\end{array}$ \\
\hline Querer & sinónimo de vontade & $\mathbf{X}$ \\
\hline Rezom & $\begin{array}{l}\text { sinónimo de lucidez ("olhos da } \\
\text { razom"), classificado como um } \\
\text { "poder", ao lado de entender; e } \\
\text { de siso. } \\
\text { A sua maior ameaça: } \\
\text { "deleitaçom da parte sensual" }\end{array}$ & $\mathbf{X}$ \\
\hline Saber & $\begin{array}{l}\text { envolve uma dimensão livresca } \\
\text { e prática }\end{array}$ & $\mathbf{X}$ \\
\hline Speriencia & forma de conhecimento & \\
\hline
\end{tabular}


(Página deixada propositadamente em branco.) 